\title{
Control of Structure and Magnetic Interaction Through Ligand Design: One-Dimensional Complexes from Ferromagnetic to Antiferromagnetic Coupling
}

\author{
Wen-Zhen Wang, ${ }^{[a, b]}$ Rayyat Huseyn Ismayilov, ${ }^{[a, b]}$ Gene-Hsiang Lee, ${ }^{[a, c]}$ Hsin-Ta Wang, ${ }^{[c]}$ \\ Rui-Ren Wang, ${ }^{[a]}$ and Shie-Ming Peng*[a,b]
}

Keywords: Coordination polymers / Copper / N ligands / Ligand design / Magnetic interactions

Four unsymmetrical pyrazine- and/or 4-picoline-modulated $N, N^{\prime}$-bis( $\alpha$-pyridyl)-2,6-diaminopyridine ligands (PMN5) were synthesized and their 1D copper(II) complexes studied. When pyrazine is a terminal ring, the ligands showed inplane and out-of-plane coordination modes and led to a onedimensional zigzag chain polymer. The orthogonal overlap of orbitals through a bridging pyrazine ring resulted in ferro- magnetic interaction. Middle-ring pyrazine-modulated ligands resulted in straight one-dimensional compounds and had antiferromagnetic coupling. The EPR spectra of the compounds showed significant covalency in the $\mathrm{Cu}-\mathrm{N}$ bonds.

(@ Wiley-VCH Verlag GmbH \& Co. KGaA, 69451 Weinheim, Germany, 2008)

\section{Introduction}

One-dimensional complexes have been a very active area in magnetic research over the past several decades because they play an intermediate role between magnetic clusters with high nuclearity and three-dimensional networks. Research on the magnetic coupling mechanism of complexes with chain structure has led to an understanding of longrange magnetic ordering and the production of molecularbased magnets. Nitrogen-heterocyclic ligands have proved to be extremely versatile, with the ability to build extended networks with different coordinate modes and the ability to mediate significant magnetic interactions between paramagnetic centers separated by more than $6 \AA^{[1]}$

Self-assembly and crystal engineering have been a much discussed topic in recent decades. Oligo- $\alpha$-pyridyl/pyrazylamino ligands are well known for their use in extended metal atom chain complexes (EMACs). ${ }^{[2]}$ Recently we developed a series of pyrazine-modulated oligo- $\alpha$-pyridylamino ligands and studied their EMACs. ${ }^{[3]}$ Furthermore, self-assembly of multidentate pyrazine-modulated oligo- $\alpha$-pyridylamino ligands with transition metals revealed versatile ligands and yielded coordination compounds from mononuclear and dinuclear complexes to 1D and high-dimension

[a] Department of Chemistry, National Taiwan University, Taipei, Taiwan, ROC

E-mail: smpeng@ntu.edu.tw

[b] Institute of Chemistry, Academia Sinica, Taipei, Taiwan, ROC

[c] Institute of Organic and Polymeric Materials, National Taipei University of Technology,

Taipei 106, Taiwan, ROC

Supporting information for this article is available on the WWW under http://www.eurjic.org or from the author. coordination polymers. ${ }^{[4]}$ Our previous research showed that antiferromagnetic coupling was observed in straight 1D complexes through both $\sigma$ and $\pi$ superexchange pathways, whereas weak ferromagnetic coupling was found in 1D complexes with zigzag structures and 2D complexes. ${ }^{[4 a]}$ We proposed that the ferromagnetic coupling mechanism is due to the unusual in-plane and out-of-plane coordination style of bridging pyrazine rings, making it possible to control magnetic interactions and the structures of the resulting polymers through artful design of ligands. In this paper we present our latest research in this area. Through the introduction of pyrazine and/or 4-picoline rings instead of pyridine rings in different positions, we obtained four new modulated unsymmetrical $N, N^{\prime}$-bis( $\alpha$-pyridyl)-2,6-diaminopyridine ligands (PMN5). Their $1 \mathrm{D} \mathrm{Cu}{ }^{\mathrm{II}}$ complex structures, magnetic properties, and bond covalencies were studied.

\section{Results and Discussion}

\section{Syntheses and Structures}

All ligands 1-4 were synthesized by a palladium-catalyzed cross-coupling reaction (Scheme 1). ${ }^{[4 a]}$

Complexes 5-8 were synthesized by treating metal perchlorate and the corresponding ligands (1-4) in methanol. The crystal structures of 5-8 are shown in Figures 1, 2, and 3 and Figure S1 (Supporting Information). Selected bond lengths and angles are listed in Table 1. In all of the complexes the nitrogen atoms of the amino groups are uncoordinated to $\mathrm{Cu}^{\mathrm{II}}$. 
<smiles>Cc1ccnc(Nc2cccc(Nc3cnccn3)n2)c1</smiles>

$N^{2}$-(4-methylpyridin-2-yl)- $N^{6}$-(pyrazin-2-yl)pyridine-2,6-diamine (mpypzda)

(1)<smiles>Cc1ccnc(Nc2cncc(Nc3cnccn3)n2)c1</smiles>

$N^{2}$-(4-methylpyridin-2-yl)- $N^{6}$-(pyrazin-2-yl)pyrazine-2,6-diamine (mpzpzda)

(3)<smiles>Cc1ccnc(Nc2cncc(Nc3ccccn3)n2)c1</smiles>

$N^{2}$-(4-methylpyridin-2-yl)- $N^{6}$-(pyridin-2-yl)pyrazine-2,6-diamine (mpzpyda)

(2)<smiles>c1ccc(Nc2cncc(Nc3cnccn3)n2)nc1</smiles>

$N^{2}$-(pyrazin-2-yl)- $N^{6}$-(pyridin-2-yl)pyrazine-2,6-diamine (pzpzda)

(4)

Scheme 1.

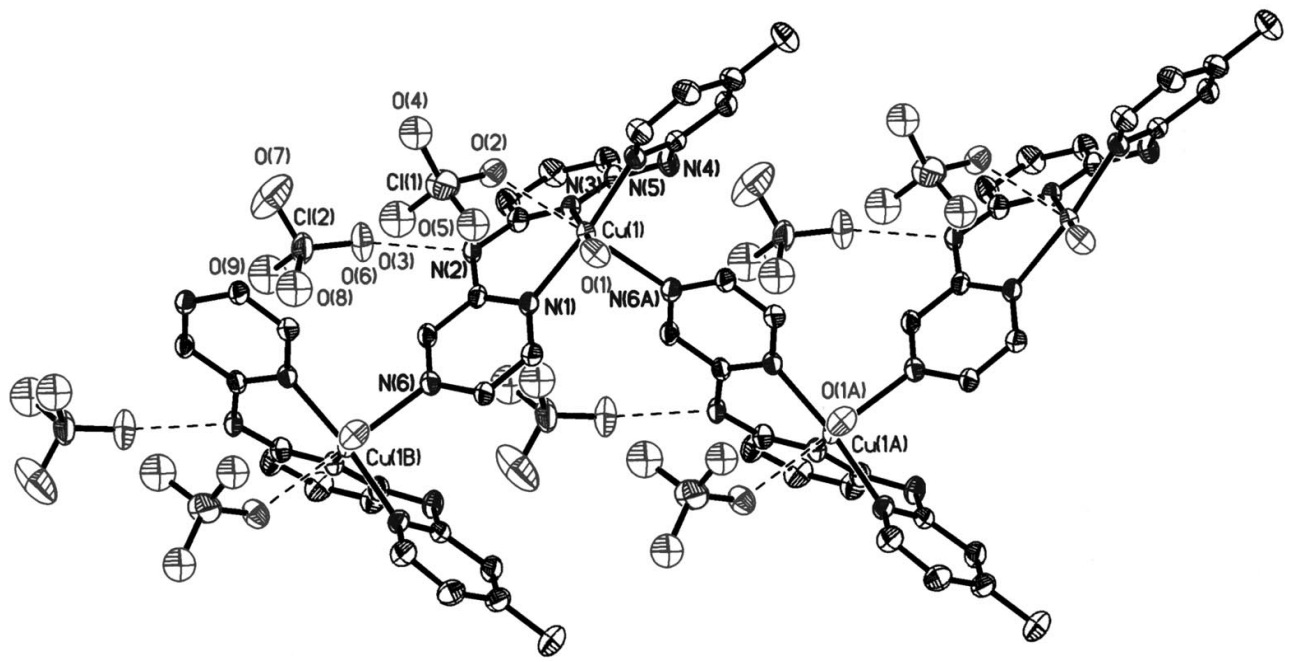

Figure 1. ORTEP drawing of the zigzag chain of $\left[\mathrm{Cu}(\mu \text {-mpypzda })\left(\mathrm{H}_{2} \mathrm{O}\right)\right]_{n}\left(\mathrm{ClO}_{4}\right)_{2 n}(\mathbf{5})$. Thermal ellipsoids are drawn at the $50 \%$ probability level. The hydrogen atoms have been omitted for clarity.

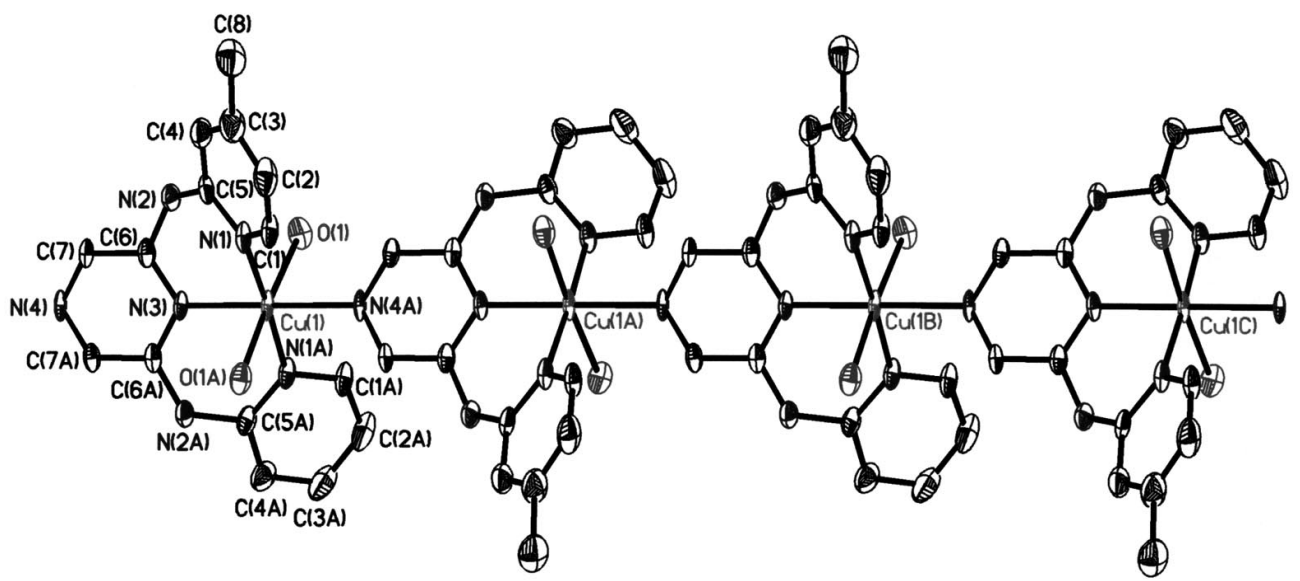

Figure 2. ORTEP drawing of the chain structure of $\left[\mathrm{Cu}(\mu \text {-mpzpyda })\left(\mathrm{H}_{2} \mathrm{O}\right)_{2}\right]_{n}\left(\mathrm{ClO}_{4}\right)_{2 n}(\mathbf{6})$. Thermal ellipsoids are drawn at the $30 \%$ probability level. The hydrogen atoms have been omitted for clarity.

$\left[\mathrm{Cu}(\mu \text {-mpypzda })\left(\mathrm{H}_{2} \mathrm{O}\right)\right]_{n}\left(\mathrm{ClO}_{4}\right)_{2 n}(\mathbf{5})$ is a one-dimensional zigzag chain polymer, in which $\mathrm{Cu}^{\mathrm{II}}$ is in an elongated octahedral coordination geometry. Three nitrogen atoms [N(1), $\mathrm{N}(3)$, and $\mathrm{N}(5)$ ] from ligand $\mathbf{1}$ and one oxygen atom [O(1)] from a coordinated water molecule make up the equatorial plane. A nitrogen atom [N(6)] of a pyrazine ring from another ligand is coordinated in one axial position, and a perchlorate anion is weakly coordinated in the other $[\mathrm{O}(2)$ 


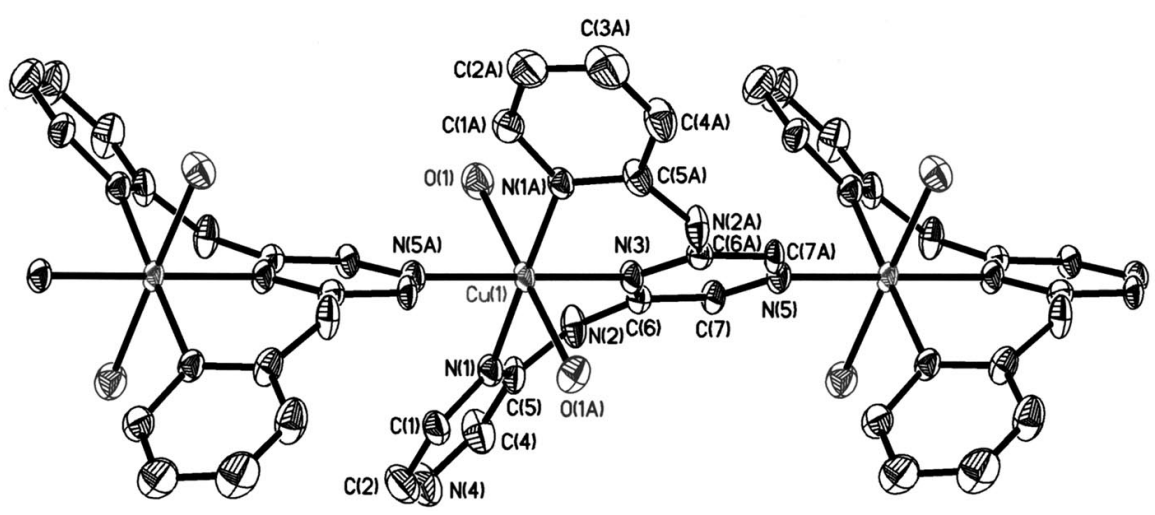

Figure 3. ORTEP drawing of the chain structure of $\left[\mathrm{Cu}(\mu \text {-pzpzda })\left(\mathrm{H}_{2} \mathrm{O}\right)_{2}\right]_{n}\left(\mathrm{ClO}_{4}\right)_{2 n}(\mathbf{8})$. Thermal ellipsoids are drawn at the $50 \%$ probability level. The hydrogen atoms have been omitted for clarity.

(a)

(b)
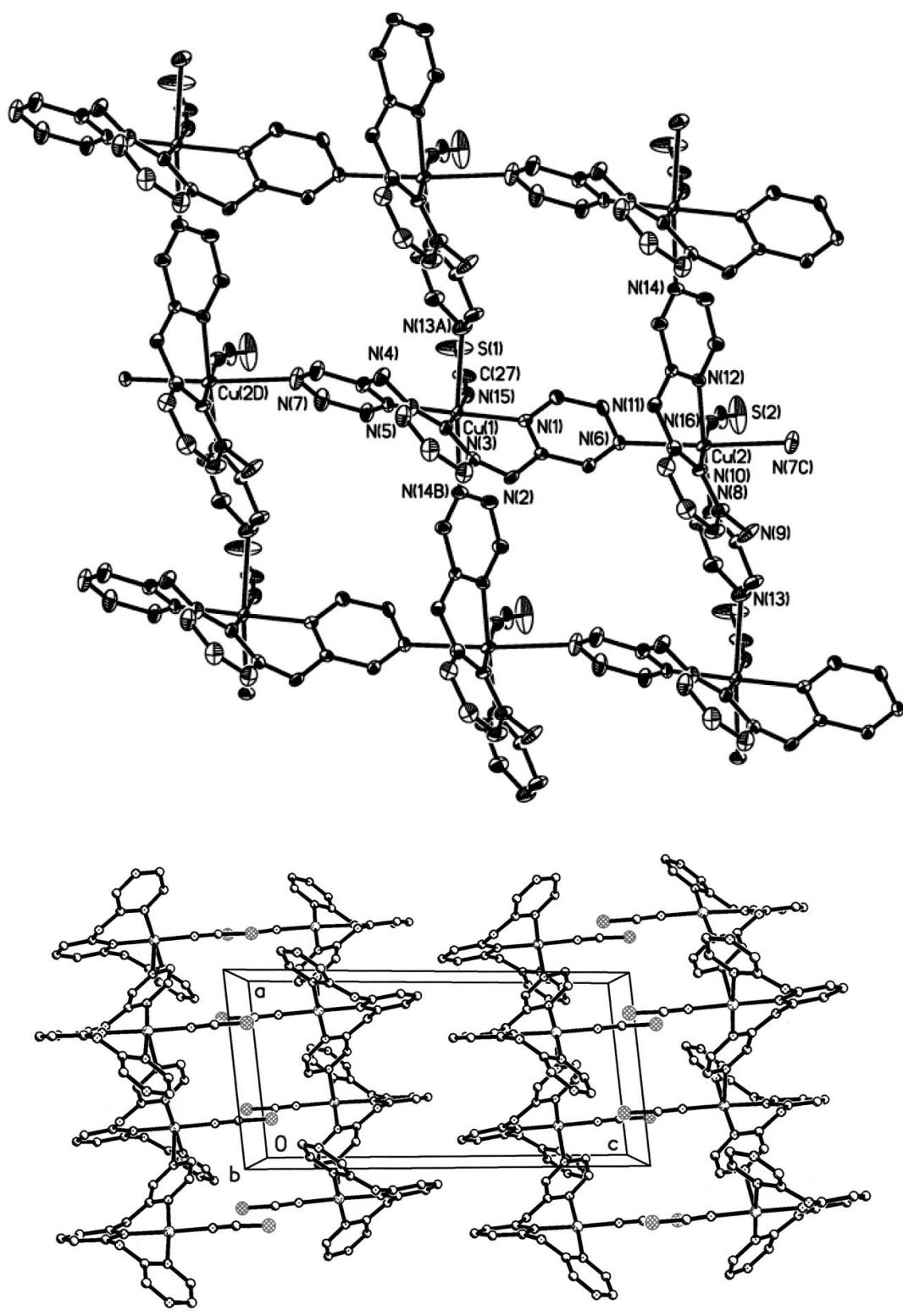

Figure 4. (a) ORTEP drawing of the 2D sheet of $\left[\mathrm{Cu}\left(\mu_{3}-\mathrm{H}_{2} \text { dpzpda) }(\mathrm{NCS})\right]_{n}\left(\mathrm{ClO}_{4}\right)_{n}(9)\right.$. Thermal ellipsoids are drawn at the $50 \%$ probability level. (b) Packing of the sheets of $\mathbf{9}$. The hydrogen atoms have been omitted for clarity. 
Table 1. Selected bond lengths $[\AA ̊]$ and angles $\left[^{\circ}\right]$ of compounds 5-9.

\begin{tabular}{|c|c|c|c|}
\hline 5 & & & \\
\hline $\mathrm{Cu}(1)-\mathrm{N}(1)$ & $1.999(5)$ & $\mathrm{Cu}(1)-\mathrm{N}(3)$ & $1.990(5)$ \\
\hline $\mathrm{Cu}(1)-\mathrm{N}(5)$ & $1.980(5)$ & $\mathrm{Cu}(1)-\mathrm{N}(6 \mathrm{~A})^{[\mathrm{a}]}$ & $2.303(5)$ \\
\hline $\mathrm{Cu}(1)-\mathrm{O}(1)$ & $2.033(5)$ & $\mathrm{Cu}(1)-\mathrm{O}(2)$ & $2.574(5)$ \\
\hline $\mathrm{N}(3)-\mathrm{Cu}(1)-\mathrm{N}(1)$ & $90.1(2)$ & $\mathrm{N}(5)-\mathrm{Cu}(1)-\mathrm{N}(1)$ & $173.8(2)$ \\
\hline $\mathrm{N}(5)-\mathrm{Cu}(1)-\mathrm{N}(3)$ & $89.7(2)$ & $\mathrm{N}(1)-\mathrm{Cu}(1)-\mathrm{O}(1)$ & $90.45(19)$ \\
\hline $\mathrm{N}(3)-\mathrm{Cu}(1)-\mathrm{O}(1)$ & $174.1(2)$ & $\mathrm{N}(5)-\mathrm{Cu}(1)-\mathrm{O}(1)$ & $89.1(2)$ \\
\hline $\mathrm{N}(1)-\mathrm{Cu}(1)-\mathrm{N}(6 \mathrm{~A})^{[\mathrm{a}]}$ & $94.07(19)$ & $\mathrm{N}(3)-\mathrm{Cu}(1)-\mathrm{N}(6 \mathrm{~A})^{[\mathrm{a}]}$ & $95.41(18)$ \\
\hline $\mathrm{N}(5)-\mathrm{Cu}(1)-\mathrm{N}(6 \mathrm{~A})^{[\mathrm{a}]}$ & $92.11(19)$ & $\mathrm{O}(1)-\mathrm{Cu}(1)-\mathrm{N}(6 \mathrm{~A})^{[\mathrm{a}]}$ & $90.39(19)$ \\
\hline $\mathrm{N}(1)-\mathrm{Cu}(1)-\mathrm{O}(2)$ & $85.38(18)$ & $\mathrm{N}(3)-\mathrm{Cu}(1)-\mathrm{O}(2)$ & $91.12(17)$ \\
\hline $\mathrm{N}(5)-\mathrm{Cu}(1)-\mathrm{O}(2)$ & $88.44(18)$ & $\mathrm{N}(6 \mathrm{~A})^{[\mathrm{a}]}-\mathrm{Cu}(1)-\mathrm{O}(2)$ & $173.44(16)$ \\
\hline $\mathrm{O}(1)-\mathrm{Cu}(1)-\mathrm{O}(2)$ & $83.09(18)$ & & \\
\hline 6 & & & \\
\hline $\mathrm{Cu}(1)-\mathrm{N}(1)$ & $1.976(5)$ & $\mathrm{Cu}(1)-\mathrm{N}(3)$ & $1.989(6)$ \\
\hline $\mathrm{Cu}(1)-\mathrm{O}(1)$ & $2.375(4)$ & $\mathrm{Cu}(1)-\mathrm{N}(4 \mathrm{~A})^{[\mathrm{b}]}$ & $2.106(6)$ \\
\hline $\mathrm{N}(1 \mathrm{~A})^{[\mathrm{c}]}-\mathrm{Cu}(1)-\mathrm{N}(1)$ & $176.9(3)$ & $\mathrm{N}(1)-\mathrm{Cu}(1)-\mathrm{N}(3)$ & $88.45(13)$ \\
\hline $\mathrm{N}(1)-\mathrm{Cu}(1)-\mathrm{N}(4 \mathrm{~A})^{[\mathrm{b}]}$ & $91.55(13)$ & $\mathrm{N}(3)-\mathrm{Cu}(1)-\mathrm{N}(4 \mathrm{~A})^{[\mathrm{b}]}$ & 180.0 \\
\hline $\mathrm{N}(1)-\mathrm{Cu}(1)-\mathrm{O}(1)$ & $92.0(2)$ & $\mathrm{N}(1)-\mathrm{Cu}(1)-\mathrm{O}(1 \mathrm{~A})^{[\mathrm{c}]}$ & $88.1(2)$ \\
\hline $\mathrm{N}(3)-\mathrm{Cu}(1)-\mathrm{O}(1)$ & $91.66(10)$ & $\mathrm{N}(4 \mathrm{~A})^{[\mathrm{b}]}-\mathrm{Cu}(1)-\mathrm{O}(1)$ & $88.34(10)$ \\
\hline $\mathrm{N}(3)-\mathrm{Cu}(1)-\mathrm{O}(1 \mathrm{~A})^{[\mathrm{c}]}$ & $91.66(10)$ & $\mathrm{O}(1 \mathrm{~A})^{[\mathrm{c}]}-\mathrm{Cu}(1)-\mathrm{O}(1)$ & $176.7(2)$ \\
\hline 7 & & & \\
\hline $\mathrm{Cu}(1)-\mathrm{N}(1)$ & $1.974(8)$ & $\mathrm{Cu}(1)-\mathrm{N}(3)$ & $1.995(9)$ \\
\hline $\mathrm{Cu}(1)-\mathrm{N}(4 \mathrm{~A})^{[\mathrm{d}]}$ & $2.027(10)$ & $\mathrm{Cu}(1)-\mathrm{O}(1)$ & $2.398(7)$ \\
\hline $\mathrm{N}(1)-\mathrm{Cu}-\mathrm{N}(1 \mathrm{~A})^{[\mathrm{e}]}$ & $179.3(4)$ & $\mathrm{N}(1)-\mathrm{Cu}-\mathrm{N}(3)$ & $89.7(2)$ \\
\hline $\mathrm{N}(1)-\mathrm{Cu}-\mathrm{N}(4 \mathrm{~A})^{[\mathrm{d}]}$ & $90.3(2)$ & $\mathrm{N}(3)-\mathrm{Cu}-\mathrm{N}(4 \mathrm{~A})^{[\mathrm{d}]}$ & $180.000(1)$ \\
\hline $\mathrm{N}(1)-\mathrm{Cu}-\mathrm{O}(1)$ & $86.8(3)$ & $\mathrm{N}(1)-\mathrm{Cu}-\mathrm{O}(1 \mathrm{~A})^{[\mathrm{e}]}$ & $93.2(3)$ \\
\hline $\mathrm{N}(3)-\mathrm{Cu}-\mathrm{O}(1)$ & $89.70(16)$ & $\mathrm{N}(4 \mathrm{~A})^{[\mathrm{d}]}-\mathrm{Cu}-\mathrm{O}(1)$ & $90.30(16)$ \\
\hline $\mathrm{O}(1 \mathrm{~A})^{[\mathrm{e}]}-\mathrm{Cu}-\mathrm{O}(1)$ & $179.4(3)$ & & \\
\hline 8 & & & \\
\hline $\mathrm{Cu}(1)-\mathrm{N}(1)$ & $1.993(5)$ & $\mathrm{Cu}(1)-\mathrm{N}(3)$ & $2.002(6)$ \\
\hline $\mathrm{Cu}(1)-\mathrm{N}(5 \mathrm{~A})^{[\mathrm{f}]}$ & $2.062(6)$ & $\mathrm{Cu}(1)-\mathrm{O}(1)$ & $2.370(4)$ \\
\hline $\mathrm{N}(1)-\mathrm{Cu}(1)-\mathrm{N}(1 \mathrm{~A})^{[\mathrm{g}]}$ & $178.6(2)$ & $\mathrm{N}(1)-\mathrm{Cu}(1)-\mathrm{N}(3)$ & $89.32(12)$ \\
\hline $\mathrm{N}(1)-\mathrm{Cu}(1)-\mathrm{N}(5 \mathrm{~A})^{[\mathrm{f}]}$ & $90.68(12)$ & $\mathrm{N}(3)-\mathrm{Cu}(1)-\mathrm{N}(5 \mathrm{~A})^{[\mathrm{f}]}$ & $180.000(1)$ \\
\hline $\mathrm{N}(1)-\mathrm{Cu}(1)-\mathrm{O}(1 \mathrm{~A})^{[\mathrm{g}]}$ & $92.19(19)$ & $\mathrm{N}(1 \mathrm{~A})^{[\mathrm{g}]}-\mathrm{Cu}(1)-\mathrm{O}(1)$ & $87.80(19)$ \\
\hline $\mathrm{N}(3)-\mathrm{Cu}(1)-\mathrm{O}(1)$ & $89.56(10)$ & $\mathrm{N}(5 \mathrm{~A})^{[\mathrm{f}]}-\mathrm{Cu}(1)-\mathrm{O}(1)$ & $90.44(10)$ \\
\hline $\mathrm{O}(1)-\mathrm{Cu}(1)-\mathrm{O}(1 \mathrm{~A})^{[\mathrm{g}]}$ & $179.1(2)$ & & \\
\hline 9 & & & \\
\hline $\mathrm{Cu}(1)-\mathrm{N}(1)$ & $2.015(3)$ & $\mathrm{Cu}(1)-\mathrm{N}(3)$ & $2.017(3)$ \\
\hline $\mathrm{Cu}(1)-\mathrm{N}(5)$ & $2.022(3)$ & $\mathrm{Cu}(1)-\mathrm{N}(13 \mathrm{~A})^{[\mathrm{h}]}$ & $2.517(4)$ \\
\hline $\mathrm{Cu}(1)-\mathrm{N}(14 \mathrm{~B})^{[\mathrm{i}]}$ & $2.419(3)$ & $\mathrm{Cu}(1)-\mathrm{N}(15)$ & $1.962(4)$ \\
\hline $\mathrm{Cu}(2)-\mathrm{N}(6)$ & $2.459(3)$ & $\mathrm{Cu}(2)-\mathrm{N}(7 \mathrm{C})^{[\mathrm{j}]}$ & $2.538(4)$ \\
\hline $\mathrm{Cu}(2)-\mathrm{N}(8)$ & $2.021(3)$ & $\mathrm{Cu}(2)-\mathrm{N}(10)$ & $2.022(3)$ \\
\hline $\mathrm{Cu}(2)-\mathrm{N}(12)$ & $2.015(3)$ & $\mathrm{Cu}(2)-\mathrm{N}(16)$ & $1.954(4)$ \\
\hline $\mathrm{N}(1)-\mathrm{Cu}(1)-\mathrm{N}(3)$ & $88.29(13)$ & $\mathrm{N}(1)-\mathrm{Cu}(1)-\mathrm{N}(5)$ & $176.31(14)$ \\
\hline $\mathrm{N}(1)-\mathrm{Cu}(1)-\mathrm{N}(13 \mathrm{~A})^{[\mathrm{h}]}$ & 90.91(13) & $\mathrm{N}(1)-\mathrm{Cu}(1)-\mathrm{N}(14 \mathrm{~B})^{[\mathrm{i}]}$ & $85.34(12)$ \\
\hline $\mathrm{N}(1)-\mathrm{Cu}(1)-\mathrm{N}(15)$ & $92.43(14)$ & $\mathrm{N}(3)-\mathrm{Cu}(1)-\mathrm{N}(5)$ & $88.46(14)$ \\
\hline $\mathrm{N}(3)-\mathrm{Cu}(1)-\mathrm{N}(13 \mathrm{~A})^{[\mathrm{h}]}$ & $92.84(13)$ & $\mathrm{N}(3)-\mathrm{Cu}(1)-\mathrm{N}(14 \mathrm{~B})^{[\mathrm{i}]}$ & $96.42(13)$ \\
\hline $\mathrm{N}(3)-\mathrm{Cu}(1)-\mathrm{N}(15)$ & $176.49(14)$ & $\mathrm{N}(5)-\mathrm{Cu}(1)-\mathrm{N}(13 \mathrm{~A})^{[\mathrm{h}]}$ & $87.50(13)$ \\
\hline $\mathrm{N}(5)-\mathrm{Cu}(1)-\mathrm{N}(14 \mathrm{~B})^{[\mathrm{i}]}$ & $96.76(13)$ & $\mathrm{N}(5)-\mathrm{Cu}(1)-\mathrm{N}(15)$ & $90.70(14)$ \\
\hline $\mathrm{N}(6)-\mathrm{Cu}(2)-\mathrm{N}(7 \mathrm{C})^{[\mathrm{ij}]}$ & $172.43(13)$ & $\mathrm{N}(6)-\mathrm{Cu}(2)-\mathrm{N}(8)$ & $95.58(13)$ \\
\hline $\mathrm{N}(6)-\mathrm{Cu}(2)-\mathrm{N}(10)$ & $93.85(13)$ & $\mathrm{N}(6)-\mathrm{Cu}(2)-\mathrm{N}(12)$ & $86.39(12)$ \\
\hline $\mathrm{N}(6)-\mathrm{Cu}(2)-\mathrm{N}(16)$ & $87.88(14)$ & $\mathrm{N}(7 \mathrm{C})^{[\mathrm{j}]}-\mathrm{Cu}(2)-\mathrm{N}(8)$ & $86.13(13)$ \\
\hline $\mathrm{N}(7 \mathrm{C})^{\mathrm{j}]}-\mathrm{Cu}(2)-\mathrm{N}(10)$ & $93.55(13)$ & $\mathrm{N}(7 \mathrm{C})^{[\mathrm{ij}]} \mathrm{Cu}(2)-\mathrm{N}(12)$ & $92.12(13)$ \\
\hline $\mathrm{N}(7 \mathrm{C})^{[\mathrm{j}]}-\mathrm{Cu}(2)-\mathrm{N}(16)$ & $84.73(14)$ & $\mathrm{N}(8)-\mathrm{Cu}(2)-\mathrm{N}(10)$ & $89.08(13)$ \\
\hline $\mathrm{N}(8)-\mathrm{Cu}(2)-\mathrm{N}(12)$ & $177.48(14)$ & $\mathrm{N}(8)-\mathrm{Cu}(2)-\mathrm{N}(16)$ & $90.41(14)$ \\
\hline $\mathrm{N}(10)-\mathrm{Cu}(2)-\mathrm{N}(12)$ & $89.22(13)$ & $\mathrm{N}(10)-\mathrm{Cu}(2)-\mathrm{N}(16)$ & $178.23(14)$ \\
\hline $\mathrm{N}(12)-\mathrm{Cu}(2)-\mathrm{N}(16)$ & $91.25(14)$ & & \\
\hline
\end{tabular}

Symmetry operation: [a] $\mathrm{A}=x,-y+1 / 2, z+1 / 2$. [b] $\mathrm{A}=x,-y, z+1 / 2$. [c] $\mathrm{A}=-x+1 / 2,-y,-z$. [d] $\mathrm{A}=x,-y, z-1 / 2$. [e] $\mathrm{A}=-x+$ $3 / 2,-y, z$. [f] $\mathrm{A}=x,-y+1 / 2, z-1 / 2$. [g] $\mathrm{A}=-x+1 / 2, y+1 / 2, z$. [h] $\mathrm{A}=x, y-1, z$. [i] $\mathrm{A}=x+1, y, z$. [j] $\mathrm{A}=x-1, y+1, z$. 
$\mathrm{Cu}(2)$ distance 2.560(4) $\AA$ ]. Ligand 1 coordinates to $\mathrm{Cu}^{\mathrm{II}}$ as a tetradentate ligand, in which it embraces one $\mathrm{Cu}^{\mathrm{II}}$ atom with three nitrogen atoms, and bridges to another $\mathrm{Cu}^{\mathrm{II}}$ atom with a pyrazine ring. Thus, through the pyrazine ring the coordination units are linked to an infinite $1 \mathrm{D}$ zigzag chain $\left(\mathrm{Cu} \cdots \mathrm{Cu} \cdots \mathrm{Cu}=100.15^{\circ}\right)$ (Figure 1). The most important structural feature of $\mathbf{5}$ is the in-plane and out-of-plane bonding style through the pyrazine rings, that is, a pyrazine spacer bridges the two magnetic centers with one side coordinated to an equatorial position of $\mathrm{Cu}^{\mathrm{II}}$ and another side coordinated to an axial position of another $\mathrm{Cu}^{\mathrm{II}}$. The $\mathrm{Cu} \cdots \mathrm{Cu}$ distance is $6.998 \AA$. Hydrogen bonds between amino groups, perchlorate anions, water molecules, and ethyl ether molecules are observed (Table 2).

Table 2.Distances $[\AA]$ of hydrogen bonds in 5-9.

\begin{tabular}{llll}
\hline $\mathbf{5}$ & & & \\
\hline $\mathrm{N} 2-\mathrm{H} \cdots \mathrm{O} 6$ & $2.912(6)$ & $\mathrm{N} 4-\mathrm{H} \cdots \mathrm{O} 7$ & $3.010(9)$ \\
$\mathrm{O} 1 \cdots \mathrm{O} 5$ & $2.894(12)$ & $\mathrm{O} 1 \cdots \mathrm{O} 1 \mathrm{~S}\left(\mathrm{H}_{2} \mathrm{O}\right)$ & $2.613(9)$ \\
$\mathrm{O} 1 \cdots \mathrm{O} 2 \mathrm{~S}($ ether $)$ & $2.720(12)$ & $\mathrm{O} 5 \cdots \mathrm{O} 1 \mathrm{~S}\left(\mathrm{H}_{2} \mathrm{O}\right)$ & $3.002(13)$ \\
\hline $\mathbf{6}$ & & & \\
\hline $\mathrm{N} 2-\mathrm{H} \cdots \mathrm{O} 2$ & $2.937(10)$ & $\mathrm{O} 1-\mathrm{H} \cdots \mathrm{O} 3$ & $3.004(10)$ \\
$\mathrm{O} 1-\mathrm{H} \cdots \mathrm{O} 4$ & $3.029(6)$ & $\mathrm{O} 1-\mathrm{H} \cdots \mathrm{O} 6$ & $2.914(13)$ \\
\hline $\mathbf{7}$ & & & \\
\hline $\mathrm{N} 2-\mathrm{H} \cdots \mathrm{O} 2$ & $2.688(5)$ & $\mathrm{N} 2-\mathrm{H} \cdots \mathrm{O} 3$ & $2.963(14)$ \\
$\mathrm{O} 1-\mathrm{H} \cdots \mathrm{O} 9$ & $3.004(15)$ & & \\
\hline $\mathbf{8}$ & & & \\
\hline $\mathrm{N} 2-\mathrm{H} \cdots \mathrm{O} 6$ & $2.915(10)$ & $\mathrm{O} 1-\mathrm{H} \cdots \mathrm{O} 3$ & $2.843(15)$ \\
$\mathrm{O} 1-\mathrm{H} \cdots \mathrm{O} 4$ & $2.855(16)$ & $\mathrm{O} 1-\mathrm{H} \cdots \mathrm{O} 7$ & $2.829(16)$ \\
\hline $\mathbf{9}$ & & & $2.830(5)$ \\
\hline $\mathrm{N} 2-\mathrm{H} \cdots \mathrm{O} 8$ & $2.956(5)$ & $\mathrm{N} 4-\mathrm{H} \cdots \mathrm{O} 6$ & \\
$\mathrm{~N} 9-\mathrm{H} \cdots \mathrm{O} 2$ & $2.960(6)$ & $\mathrm{N} 11-\mathrm{H} \cdots \mathrm{O} 4$ & $2.972(7)$ \\
\hline
\end{tabular}

[Cu( $\mu$-mpzpyda $\left.)\left(\mathrm{H}_{2} \mathrm{O}\right)_{2}\right]_{n}\left(\mathrm{ClO}_{4}\right)_{2 n}$ (6), $[\mathrm{Cu}(\mu$-mpzpzda)$\left.\left(\mathrm{H}_{2} \mathrm{O}\right)\left(\mathrm{CH}_{3} \mathrm{OH}\right)\right]_{n}\left(\mathrm{ClO}_{4}\right)_{2 n}$ (7), and $\left[\mathrm{Cu}(\mu \text {-pzpzda })\left(\mathrm{H}_{2} \mathrm{O}\right)_{2}\right]_{n^{-}}$ $\left(\mathrm{ClO}_{4}\right)_{2 n}(\mathbf{8})$ exhibit similar one-dimensional straight-chain polymeric structures. A $C_{2}$ axis runs along the molecular chain, which extends parallel to the $c$ axis. The occupancy of $\mathrm{C}(8)$ in $\mathbf{6}, \mathrm{C}(9), \mathrm{N}(5), \mathrm{C}(3)$, and $\mathrm{C}(8)$ in 7 , and $\mathrm{C}(3)$ and $\mathrm{N}(4)$ in $\mathbf{8}$ is 0.5 , and all these atoms are in general positions. In each of the compounds, $\mathrm{Cu}^{\mathrm{II}}$ is six-coordinate and undergoes an elongated Jahn-Teller distortion with an equatorial plane constructed through four nitrogen atoms and the axial positions occupied by two weakly coordinated oxygen atoms in water or methanol molecules. Ligands are coordinated to $\mathrm{Cu}^{\mathrm{II}}$ in the same way as in complex 5. However, both of the nitrogen atoms in one pyrazine ring are coordinated to $\mathrm{Cu}^{\mathrm{II}}$ in equatorial positions. The molecular chain is straight, which is the favorite structure for $\mathrm{Cu}^{\mathrm{II}}$ complexes of PMN5 with pyrazine as the middle ring of the ligand. The $\mathrm{Cu} \cdots \mathrm{Cu}$ distance is $6.847 \AA$ for $\mathbf{6}$, and $6.831 \AA$ for 7 and $\mathbf{8}$. There is no solvent molecule crystallized in the cell. Extensive hydrogen bonds between amino groups, perchlorate anions, and water molecules are observed in $\mathbf{6}, \mathbf{7}$, and $\mathbf{8}$ (Table 2), resulting in 3D networks of $\mathbf{6}$ and $\mathbf{8}$. There was, however, no interchain hydrogen bond in 7 .

Complex $\left[\mathrm{Cu}\left(\mu_{3}-\mathrm{H}_{2} \mathrm{dpzpda}\right)(\mathrm{NCS})\right]_{n}\left(\mathrm{ClO}_{4}\right)_{n}$ (9) was designed to provide another example of in-plane and out-ofplane bridging style through the pyrazine rings. Complex 9 was obtained simply from the addition of NaNCS to the solution containing the $2 \mathrm{D}$ compound $\left[\mathrm{Cu}_{2}\left(\mu_{3}-\mathrm{H}_{2} \mathrm{dpzpda}\right)_{2}\right.$ $\left.\left(\mathrm{H}_{2} \mathrm{O}\right)_{2}\right]_{n}\left(\mathrm{ClO}_{4}\right)_{4 n} \cdot{ }^{[4 \mathrm{a}]}$ After the reaction, the water molecule was substituted by a $\mathrm{NCS}^{-}$anion that had the cationic $[2 \times 2]$ grid structure remaining intact. The sulfur atom in the thiocyanate anion is disordered on two positions, and the probability is 0.25 for one sulfur atom and 0.75 for another. Both independent $\mathrm{Cu}^{\mathrm{II}}$ units in 9 were six-coordinate with an elongated octahedral geometry (Figure 4). The average distance was 2.004(4) $\AA$ for in-plane $\mathrm{Cu}-\mathrm{N}$ bonds, and 2.483(3) $\AA$ for out-of-plane $\mathrm{Cu}-\mathrm{N}$ bonds. The angle between coordination equatorial planes around $\mathrm{Cu}(1)$ and $\mathrm{Cu}(2)$ was $80.7^{\circ}$. The Jahn-Teller distortion was stronger than in the initial complex $\left[\mathrm{Cu}_{2}\left(\mu_{3}-\mathrm{H}_{2} \mathrm{dpzpda}\right)_{2}\left(\mathrm{H}_{2} \mathrm{O}\right)_{2}\right]_{n^{-}}$ $\left(\mathrm{ClO}_{4}\right)_{4 n}$. The average $\mathrm{Cu} \cdots \mathrm{Cu}$ distance was $7.209 \AA$. The molecular grid deviated considerably from orthogonal, with a $\mathrm{Cu} 1-\mathrm{Cu} 2-\mathrm{Cu} 1$ angle of $102.65^{\circ}$ and a $\mathrm{Cu} 2-\mathrm{Cu} 1-\mathrm{Cu} 2$ angle of $77.35^{\circ}$. Extensive hydrogen bonds exist (Table 2), whereas no linkage between the 2D layers of 9 was observed.

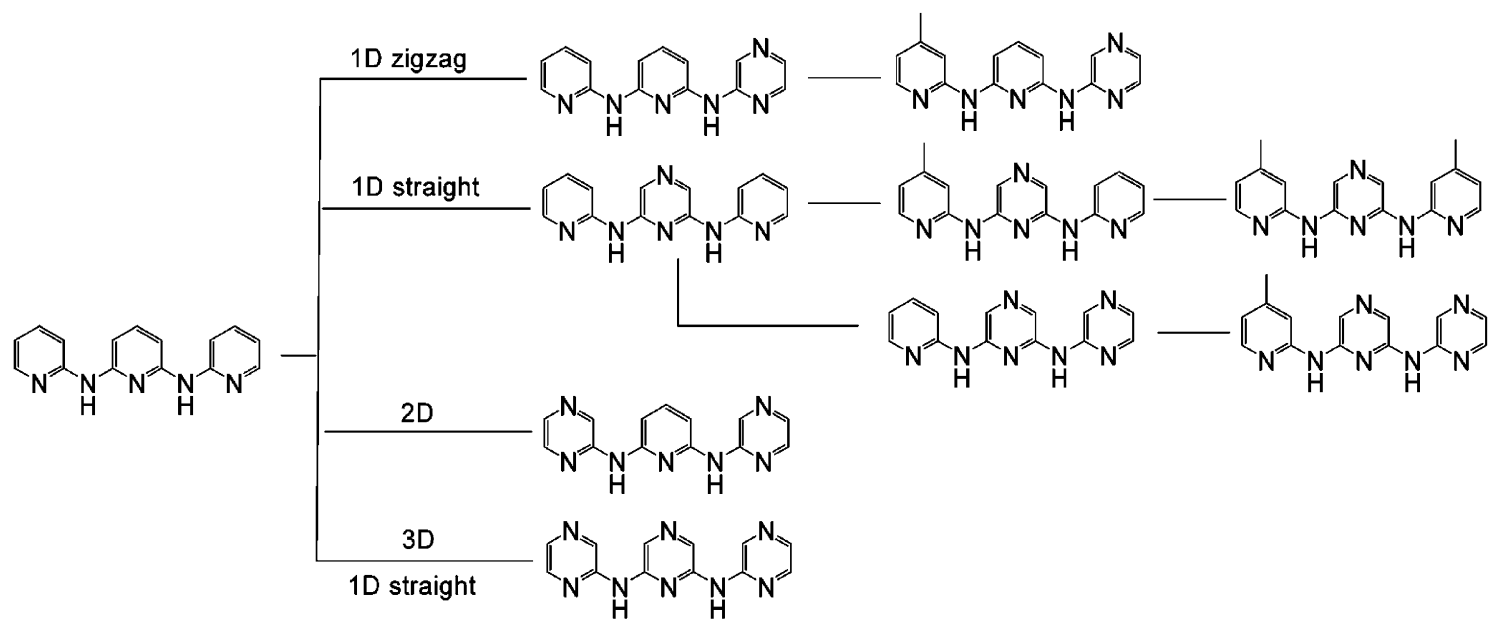

Scheme 2. PMN5 ligands and structures of resultant $\mathrm{Cu}^{\mathrm{II}}$ complexes. ${ }^{[4 a]}$ 
From pyrazine- and picoline-modulated PMN5 ligands and the structures of their $\mathrm{Cu}^{\mathrm{II}}$ complexes, ${ }^{[4 \mathrm{a}]}$ the following conclusions can be drawn (Scheme 2): (1) The introduction of a methyl group leads to unsymmetrical ligands and thus modifies the electronic distribution of the ligands. However, the structure of $\mathrm{Cu}^{\mathrm{II}}$ complexes depends mainly on the site of the pyrazine ring. Middle-ring pyrazine-modulated ligands result in straight one-dimensional compounds. When the pyrazine-modulated site is a terminal ring, a one-dimensional zigzag chain polymer results. (2) Methyl groups contribute little to the construction of the $\mathrm{Cu}^{\mathrm{II}}$ complex polymer structures. Isostructures of complexes were obtained by using mpypzda (1), and $N$-(pyrazin-2-yl)- $N^{\prime}$-(pyridin-2-yl)pyridine-2,6-diamine $\left(\mathrm{H}_{2}\right.$ pzppda) ligands. (3) When ligands have more than one pyrazine ring, a 1D straight chain is the favorable structure for copper(II) complexes; however, 2D and 3D structures are also possible. Both ligands 3 and 4 resulted in 1D straight-chain complexes ( $\mathbf{7}$ and $\mathbf{8}$ ) rather than $1 \mathrm{D}$ zigzag or $2 \mathrm{D}$ structures.

\section{Magnetic Properties}

The magnetic susceptibility of complexes $\mathbf{5}, \mathbf{7}, \mathbf{8}$, and $\mathbf{9}$ was measured in the range $2-300 \mathrm{~K}$ and of complex 6 in the range $5-300 \mathrm{~K}$. The $\mu_{\text {eff }}$ values of all complexes at room temperature $(300 \mathrm{~K})$ were slightly higher than the expected spin-only value for noninteracting $\mathrm{Cu}^{\mathrm{II}}\left(1.73 \mu_{\mathrm{B}}\right)$ and ranged from 1.78 to $1.87 \mu_{\mathrm{B}}$. The magnetic behaviors of $\mathbf{6}$, $\mathbf{7}$, and $\mathbf{8}$ are similar, showing typical antiferromagnetic coupling. The $\mu_{\text {eff }}$ values decreased slowly as the temperature was lowered, and then declined abruptly below $50 \mathrm{~K}$. Therefore, the temperature dependence of the magnetic susceptibility of 6-8 was modeled by using a theoretical expression deduced from the spin Hamiltonian $H=-2$ $J \sum_{i \neq j} S_{i} S_{j}(S=1 / 2),{ }^{[5]}$ and modified to include an amount of uncoupled species, $\rho$ (Figures 5, S2, and S3).

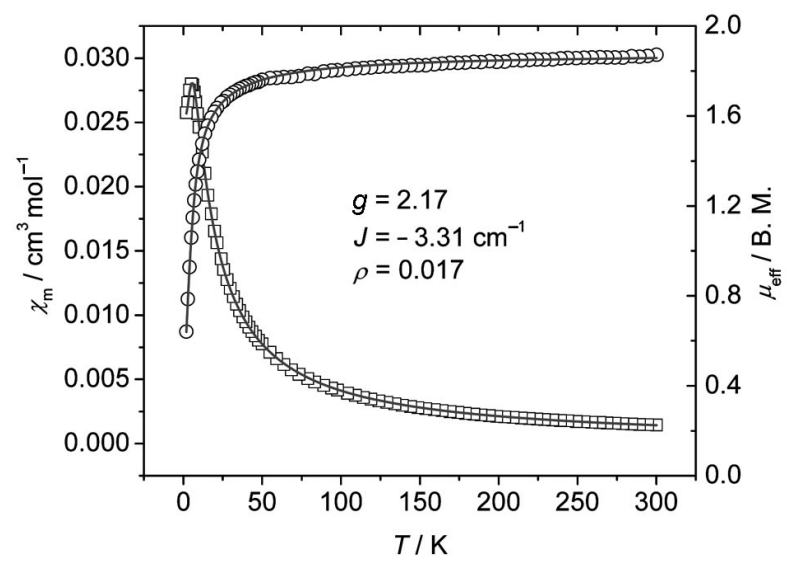

Figure 5. Temperature dependence of the magnetic moment $\mu_{\text {eff }}(\bigcirc)$ and the molar susceptibility $\chi_{\mathrm{M}}(\square)$ for 7 . Solid lines represent least-squares fit obtained by using the antiferromagnetic 1D Heisenberg model.
The results of least-squares fitting of experimental data are very close to each other, with $g$ values in the range 2.112.17 and $J$ values in the range -2.60 to $-3.31 \mathrm{~cm}^{-1}$, as shown in Table 3. The results are similar to those of analogous complexes previously reported and consistent with the system in which the interaction was intermediated through both $\sigma$ and $\pi$ pathways. ${ }^{[1 a, 4 a, 6]}$

Table 3. Magnetic data for complexes 5-9.

\begin{tabular}{lcccc}
\hline Complex & $g$ & $J\left[\mathrm{~cm}^{-1}\right]$ & $\rho$ & $F^{[\mathrm{a}]}$ \\
\hline $\mathbf{5}$ & 2.07 & 0.12 & 0 & $2.3 \times 10^{-7}$ \\
$\mathbf{6}$ & 2.12 & -2.60 & 0.033 & $1.4 \times 10^{-7}$ \\
$\mathbf{7}$ & 2.17 & -3.31 & 0.017 & $5.5 \times 10^{-7}$ \\
$\mathbf{8}$ & 2.11 & -2.66 & 0.052 & $1.9 \times 10^{-6}$ \\
$\mathbf{9}$ & 2.09 & 0.11 & 0 & $4.5 \times 10^{-6}$ \\
\hline
\end{tabular}

[a] $F$ is defined as $\Sigma\left(\chi_{i \exp }\right)^{-1}\left(\chi_{i \exp }-\chi_{i \text { theo }}\right)^{2}$.

A maximum magnetic susceptibility was observed at $5 \mathrm{~K}$ for compound 7, which is typical of an infinite one-dimensional Heisenberg system with negative $J$ values and defined theoretically by:

$$
k T_{\max } /|J|=1.282
$$

The fitting result is in accordance with this formula.

The molecular magnetic moments of $\mathbf{5}$ showed a slight increase as the temperature decreased, reaching a maximum at $90 \mathrm{~K}$, and then decreasing to $1.73 \mu_{\mathrm{B}}$ at $2 \mathrm{~K}$. The magnetic behavior is similar to that observed in the $1 \mathrm{D}$ zigzag complex $\left[\mathrm{Cu}\left(\mu-\mathrm{H}_{2} \text { pzppda }\right)\left(\mathrm{H}_{2} \mathrm{O}\right)\right]_{n}\left(\mathrm{ClO}_{4}\right)_{2 n}$ previously reported. ${ }^{[4 a]}$ We found the magnetism of this system to be in accordance with a result of cooperation of a weak ferromagnetic coupling with an interchain antiferromagnetic interaction. The experimental data were fitted by using the ferromagnetic chain model $\left(H=-2 J \sum_{i} S_{i} S_{i+1}\right)$ including an interchain antiferromagnetic interaction interpreted as $\theta$ [Equation (1)]. ${ }^{[7]}$

$\chi=N g^{2} \beta^{2}(A / B)^{2 / 3} / 4 \mathrm{~K}(T-\theta)$

in which $A=1.0+5.7979916 y+16.902653 y^{2}+$ $29.376885 y^{3}+29.832959 y^{4}+14.036918 y^{5}, B=1.0+$ $2.7979916 y+7.0086780 y^{2}+8.6538644 y^{3}+4.5743114 y^{4}$, and $y=2|J| / k T$.

The result excellently matched the experimental data result of $g=2.07, J=0.12 \mathrm{~cm}^{-1}$, and $\theta=-0.82 \mathrm{~K}$ (Figure 6).

Complex 9 showed similar magnetic behavior to that of 5. The magnetic data of $\mathbf{9}$ were approximately analyzed with a theoretical expression for a one-dimensional $S=1 / 2$ system. The experimental result was in excellent agreement with the theoretical analysis, resulting in $g=2.09, J=$ $0.11 \mathrm{~cm}^{-1}$, and $\theta=-0.65 \mathrm{~K}$ (Figure 7). ${ }^{[8]}$

The magnetic results of $\mathbf{5}$ and $\mathbf{9}$ are very similar to that of our previously reported complexes, $\left[\mathrm{Cu}\left(\mu-\mathrm{H}_{2}\right.\right.$ pzppda)$\left.\left(\mathrm{H}_{2} \mathrm{O}\right)\right]_{n}\left(\mathrm{ClO}_{4}\right)_{2 n}$ and $\left[\mathrm{Cu}_{2}\left(\mu_{3}-\mathrm{H}_{2} \mathrm{dpzpda}\right)_{2}\left(\mathrm{H}_{2} \mathrm{O}\right)_{2}\right]_{n}\left(\mathrm{ClO}_{4}\right)_{4 n}$ $\left\{\mathrm{H}_{2}\right.$ pzppda $=(N$-pyrazin-2-yl $)\left(N^{\prime}\right.$-pyridin-2-yl $)$ pyridine2,6-diamine, $\mathrm{H}_{2}$ dpzpda $=N, N^{\prime}$-bis(pyrazin-2-yl)pyridine2,6-diamine $\}{ }^{[4 a]}$ We postulated that the unusual ferromagnetic interaction resulted from orthogonal overlap of magnetic orbitals between two adjacent $\mathrm{Cu}^{\mathrm{II}}$ centers through 


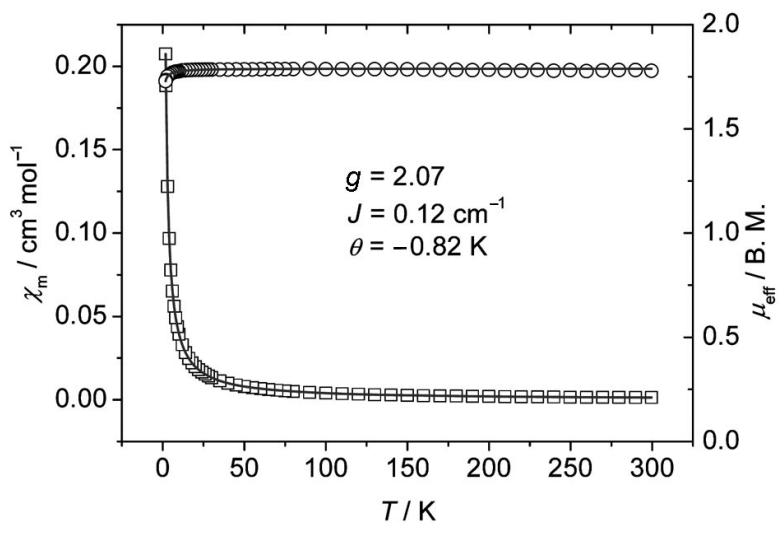

Figure 6. Temperature dependence of the magnetic moment $\mu_{\text {eff }}(\bigcirc)$ and the molar susceptibility $\chi_{M}(\square)$ for $\mathbf{5}$. Solid lines represent least-squares fit obtained by using Equation (1).

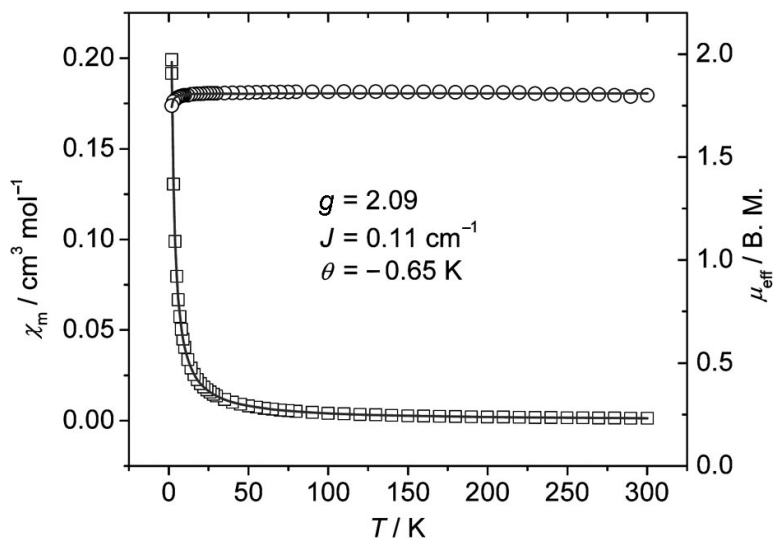

Figure 7. Temperature dependence of the magnetic moment $\mu_{\mathrm{eff}}(\bigcirc)$ and the molar susceptibility $\chi_{M}(\square)$ for 9. Solid lines represent least-squares fit by using Equation (1).

the pyrazine bridge and the resultant unique in-plane and out-of-plane coordination mode of the bridging pyrazine ring. As described above, orthogonal overlap of magnetic orbitals was observed for both $\mathbf{5}$ and $\mathbf{9}$, and the results support this ferromagnetic coupling mechanism despite the electron density on $\mathrm{d}_{z^{2}}$ being low because of the elongated Jahn-Teller distortion and the magnetic coupling being weak.

\section{EPR Spectroscopy}

X-band EPR spectra of complexes 5-8 in methanol solution at room temperature and at $77 \mathrm{~K}$ showed typical axial patterns of the $\mathrm{Cu}^{\mathrm{II}}$ compounds. All the spectra were similar and showed well-resolved hyperfine structures resulting from the ${ }^{63} \mathrm{Cu}$ and ${ }^{65} \mathrm{Cu}$ paramagnetic isotopes (both $I=$ $3 / 2$ ), which may be due to the effective magnetic dilution resulting from the polymer structure, in which $\mathrm{Cu}^{\mathrm{II}}$ centers were separated by about $7 \AA$ from each other by a bridging pyrazine (Figure 8). For complexes 5-8, three hyperfine lines in the parallel region were observed and the fourth was overlapped with a perpendicular line, yielding $g_{\|}=2.27$, $g_{\perp}=2.06,<g>=2.13, A_{\|}^{\mathrm{Cu}}=150 \times 10^{-4} \mathrm{~cm}^{-1}, A_{\perp}{ }^{\mathrm{Cu}}=$ $7.5 \times 10^{-4} \mathrm{~cm}^{-1}$, and $A^{0}=55 \times 10^{-4} \mathrm{~cm}^{-1}$ [calculated from the expression: $\left.A^{0}=\left(2 A_{\perp}+A_{\|}\right) / 3\right]$. The resulting $g_{\|}>g_{\perp}$ $>g_{\mathrm{e}}$ and $\left|A_{\perp}\right|<<\mid A_{\|} \approx(120-200) \times 10^{-4} \mathrm{~cm}^{-1}$ indicated a $\mathrm{d}_{x^{2}-y^{2}}$ ground state and agreed with the $\mathrm{X}$-ray structures of an elongated octahedral coordination geometry for the $\mathrm{Cu}^{\mathrm{II}}$ ion. The spectra at $77 \mathrm{~K}$ showed clear ${ }^{14} \mathrm{~N}$ superhyperfine lines $(I=1)$, yielding $A_{\|}{ }^{\mathrm{N}}=17.8 \times 10^{-4} \mathrm{~cm}^{-1}$ and $A_{\perp}{ }^{\mathrm{N}}=$ $7.5 \times 10^{-4} \mathrm{~cm}^{-1}$. The split resulting from four equivalent nitrogen atoms theoretically produces nine lines. The superhyperfine coupling (shfs) strongly suggests a large amount of electronic delocalization from the $\mathrm{d}$ orbitals onto the ligands. ${ }^{[9 a]}$

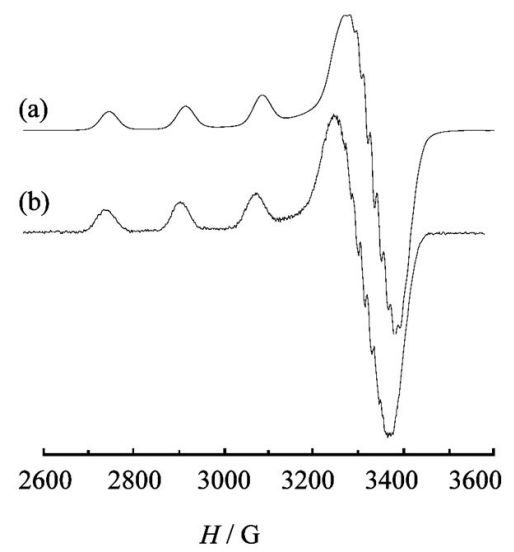

Figure 8. (a) EPR spectrum observed for $\mathbf{5}$ in methanol solution at $77 \mathrm{~K}$; (b) the simulated line shape spectrum for (a).

The $g$ value expressions including orbital reduction coefficients $k$ are: ${ }^{[9 b]}$

$$
\begin{aligned}
& g_{\|}=2.002-8 \lambda k_{\|}{ }^{2} / E\left[{ }^{2} \mathrm{~B}_{2 \mathrm{~g}}(x y)\right] \\
& g_{\perp}=2.002-2 \lambda k_{\perp}^{2} / E\left[{ }^{2} \mathrm{E}_{\mathrm{g}}(x z, y z)\right]
\end{aligned}
$$

where $\lambda$ represents the spin-orbital coupling constant $(\lambda=$ $-830 \mathrm{~cm}^{-1}$ for the free $\mathrm{Cu}^{\mathrm{II}}$ ion), and $E\left[{ }^{2} \mathrm{~B}_{2 \mathrm{~g}}(x y)\right]$ and $E\left[{ }^{2} \mathrm{E}_{\mathrm{g}}(x z, y z)\right]$ are the energies of the two excited states relative to the ${ }^{2} \mathrm{~B}_{1 \mathrm{~g}}\left(x^{2}-y^{2}\right)$ ground state corresponding to elongated forms from the Jahn-Teller distortion. The individual excited state energies lie very close to each other and cannot be resolved in the electronic spectrum. Substitution of the observed excited state energies $E\left[{ }^{2} \mathrm{~B}_{2 \mathrm{~g}}(x y)\right] \approx E\left[{ }^{2} \mathrm{E}_{\mathrm{g}}(x z, y z)\right]$ into Equations (2) and (3) yields the estimates $k_{\|} \approx 0.78$ 0.80 and $k_{\perp} \approx 0.74-0.76$. The delocalization of the unpaired electron onto the ligands is in a reasonable range $22-26 \%$, and implies the substantial covalency of the $\mathrm{Cu}-\mathrm{N}$ bonds (Table 4) ${ }^{[9 \mathrm{~d}]}$

Table 4. EPR data and bond parameters for complexes 5-8.

\begin{tabular}{lccccc}
\hline Compound & $g_{\|}$ & $g_{\perp}$ & $E\left[\mathrm{~cm}^{-1}\right]$ & $k_{\|}$ & $k_{\perp}$ \\
\hline $\mathbf{5}$ & 2.268 & 2.062 & 15267 & 0.782 & 0.743 \\
$\mathbf{6}$ & 2.270 & 2.062 & 15198 & 0.783 & 0.741 \\
$\mathbf{7}$ & 2.273 & 2.062 & 15823 & 0.804 & 0.756 \\
$\mathbf{8}$ & 2.272 & 2.062 & 15314 & 0.789 & 0.744 \\
\hline
\end{tabular}


Expressions for the hyperfine parameters of complexes of tetragonal symmetry with a single unpaired electron in the $\mathrm{d}_{x^{2}-y^{2}}$ or $\mathrm{d}_{x y}$ orbital are:[9b]

$A_{\|}=P\left(-4 a^{2} / 7-K a^{2}+3 \delta g_{\perp} / 7+3 \delta g_{\|}\right)$

$A_{\perp}=P\left(2 \alpha^{2} / 7-K \alpha^{2}+11 \delta g_{\perp} / 14\right)$

where $P$ represents the basic interaction between the electron spin and the nuclear magnetic moments and has the approximate value $0.063 \mathrm{~cm}^{-1}$ for $\mathrm{Cu}^{\mathrm{II}}$, factor $K$ describes the isotropic hyperfine contribution owing to unpaired electron spin density in s orbitals, $a^{2}$ is the fractional unpaired spin density on the metal, and $\delta$ is the observed $g$ shift $\delta g_{\perp}$ $=g_{\perp}-g_{\mathrm{e}}$ and $\delta g_{\|}=g_{\|}-g_{\mathrm{e}}$. Substituting the values $\delta g_{\perp}=$ 0.060 and $\delta g_{\|}=0.270$ into Equations (4) and (5) yields the estimates $K \approx 0.32$ and $a^{2}=0.80$. The values are consistent with the reference results and the fractional unpaired spin density on the metal agrees well with that suggested by the orbital reduction coefficients $k\left(k_{\|} \approx 0.78\right.$ and $\left.k_{\perp} \approx 0.74\right) .{ }^{[9]}$

\section{Conclusions}

In this work we present four new unsymmetrical, pyrazine- and/or picoline-modulated PMN5 $\left[N, N^{\prime}\right.$-bis $(\alpha$-pyridyl)-2,6-diaminopyridine ligands] ligands. This set of ligands afforded 1D structure coordination polymers in the reactions with $\mathrm{Cu}^{\mathrm{II}}$. Methyl groups contribute little to the construction of the $\mathrm{Cu}^{\mathrm{II}}$ complex polymer structures. When pyrazine was a terminal ring, the ligands showed in-plane and out-of-plane coordination modes and led to a one-dimensional zigzag chain polymer, which resulted in the orthogonal overlap of magnetic orbitals. Middle ring pyrazine-modulated ligands usually resulted in straight one-dimensional compounds, and they exhibited antiferromagnetic coupling. The orthogonal overlap of orbitals through the bridging pyrazine ring resulted in ferromagnetic interaction, which is depleted from Jahn-Teller distortion. The EPR spectra of the compounds showed significant covalency in the $\mathrm{Cu}-\mathrm{N}$ bonds.

\section{Experimental Section}

Materials: All reagents and solvents were obtained from commercial sources and were used without further purification unless otherwise noted. $\quad N, N^{\prime}$-Bis(pyrazin-2-yl)pyridine-2,6-diamine $\left(\mathrm{H}_{2} \mathrm{dpzpda}\right)$ was synthesized according to a previous procedure. ${ }^{\text {4a] }}$ The preparation of starting materials $N$-(6-bromopyridin-2-yl)pyrazin-2-amine, 6-chloro- $N$-(pyridin-2-yl)pyrazin-2-amine, and $N$-(6chloropyrazin-2-yl)pyrazin-2-amine is provided in the Supporting Information.

Caution! Perchlorate salts are potentially explosive and should only be used in small quantities and handled with the necessary precautions.

Physical Measurements: Absorption spectra were recorded with a Hewlett Packard Model 8453 spectrophotometer. IR spectra were performed from $\mathrm{KBr}$ pellets with a Perkin-Elmer FTIR Spectrometer PARAGON 1000 in the range $400-4000 \mathrm{~cm}^{-1}$. FAB-MS mass spectra were obtained with a JEOL JMS-700 HF double focusing spectrometer operating in the positive-ion detection mode. Molar magnetic susceptibility was recorded with a SQUID system with 2000 GAUSS external magnetic field. X-band EPR spectra were recorded with a Bruker E500 spectrometer equipped with a Bruker TE102 cavity. Sample temperature at $77 \mathrm{~K}$ was maintained using a finger Dewar filled with liquid nitrogen.

$N^{2}$-(4-Methylpyridin-2-yl)- $N^{6}$-(pyrazin-2-yl)pyridine-2,6-diamine (mpypzda) (1): The reaction of $N$-(6-bromopyridin-2-yl)pyrazin-2amine $(5.02 \mathrm{~g}, 0.02 \mathrm{~mol})$ and 2 -amino-4-picoline $(2.592 \mathrm{~g}$, $0.024 \mathrm{~mol})$ in the presence of $\mathrm{Pd}_{2}(\mathrm{dba})_{3}(0.366 \mathrm{~g}, 2 \mathrm{~mol}-\%)$, BINAP $(0.498 \mathrm{~g}, 4 \mathrm{~mol}-\%)$, and $t \mathrm{BuONa}(3.267 \mathrm{~g}, 0.034 \mathrm{~mol})$ in benzene $(100 \mathrm{~mL})$ under an atmosphere of argon for $48 \mathrm{~h}$ gave a crude product of 1 . Purification by column chromatography over silica gel with dichloromethane/acetone (7:3) as eluent gave colorless crystals of 1 after evaporation. Yield: 4.05 g, 73\%; m.p. $209^{\circ} \mathrm{C}$. IR (KBr): $\tilde{v}=3272,3196(\mathrm{~m}), 3046(\mathrm{~m}), 1610(\mathrm{~m}), 1562(\mathrm{~m}), 1553(\mathrm{~m}), 1524$ (m), $1422(\mathrm{~s}), 1390(\mathrm{~s}), 1348(\mathrm{~m}), 1322(\mathrm{~m}), 1301(\mathrm{~m}), 1280(\mathrm{~m})$, 1195 (w), 1156 (m), 1033 (w), 1004 (w), 992 (w), $876(\mathrm{w}), 814(\mathrm{~m})$, $793(\mathrm{~m}), 523(\mathrm{~m}), 447(\mathrm{w}), 413(\mathrm{w}) \mathrm{cm}^{-1}$. UV/Vis $\left(\mathrm{CH}_{3} \mathrm{OH}\right): \lambda(\varepsilon$, $\left.\mathrm{dm}^{3} \mathrm{~mol}^{-1} \mathrm{~cm}^{-1}\right)=206\left(1.65 \times 10^{4}\right), 228\left(9.55 \times 10^{3}\right), 262$ $\left(2.34 \times 10^{4}\right), 275\left(2.42 \times 10^{4}\right), 344\left(1.60 \times 10^{4}\right) \mathrm{nm} .{ }^{1} \mathrm{H}$ NMR [400 MHz, $\left.\left(\mathrm{CD}_{3}\right)_{2} \mathrm{SO}, 25^{\circ} \mathrm{C}\right]: \delta=9.73(\mathrm{~s}, 1 \mathrm{H},-\mathrm{NH}), 9.42(\mathrm{~s}, 1 \mathrm{H}$, -NH), 9.34-9.33 (m, $1 \mathrm{H}, \mathrm{Ar}-\mathrm{H}), 8.22$ (s, $1 \mathrm{H}, \mathrm{Ar}-\mathrm{H}), 8.08-8.06$ (m, $2 \mathrm{H}, \mathrm{Ar}-\mathrm{H}), 7.56-7.51$ (m, $2 \mathrm{H}, \mathrm{Ar}-\mathrm{H}), 7.27-7.24$ (m, $1 \mathrm{H}, \mathrm{Ar}-\mathrm{H})$, 6.94-6.92 (m, 1 H, Ar-H), 6.70 (s, $1 \mathrm{H}, \mathrm{Ar}-\mathrm{H}), 2.26\left(\mathrm{~s}, 3 \mathrm{H},-\mathrm{CH}_{3}\right)$ ppm. $\mathrm{C}_{15} \mathrm{H}_{14} \mathrm{~N}_{6}$ (278.32): calcd. C 64.73, H 5.07, N 30.20; found C $64.65, \mathrm{H} 4.99$, N 29.85.

$N^{2}$-(4-Methylpyridin-2-yl)- $N^{6}$-(pyridin-2-yl)pyrazine-2,6-diamine (mpzpyda) (2): The preparation process for $\mathbf{2}$ was similar to that of 1 except that 6-chloro- $N$-(pyridin-2-yl)pyrazin-2-amine $(4.12 \mathrm{~g}$, $0.02 \mathrm{~mol})$ was used instead of $N$-(6-bromopyridin-2-yl)pyrazin-2amine, the reaction time was $72 \mathrm{~h}$, and dichloromethane/acetone (3:2) was used as eluent for column chromatography. Yield: $3.60 \mathrm{~g}$, $65 \%$; m.p. $180{ }^{\circ} \mathrm{C}$. IR $(\mathrm{KBr}): \tilde{v}=3265(\mathrm{~m}), 3159(\mathrm{~m}), 3052(\mathrm{~m})$, 1614 (m), 1515 (m), 1490 (m), 1434 (s), 1404 (m), 1338 (m), 1315 (m), 1289 (m), 1169 (s), 1144 (m), 1052 (w), 992 (m), 956 (w), 831 (w), $770(\mathrm{~m}), 733(\mathrm{w}), 668(\mathrm{w}), 618(\mathrm{w}), 522(\mathrm{w}), 470(\mathrm{w}), 450(\mathrm{w})$ $\mathrm{cm}^{-1}$. UV/Vis $\left(\mathrm{CH}_{3} \mathrm{OH}\right): \lambda\left(\varepsilon, \mathrm{dm}^{3} \mathrm{~mol}^{-1} \mathrm{~cm}^{-1}\right)=206\left(1.59 \times 10^{4}\right)$, $261\left(2.60 \times 10^{4}\right), 272\left(2.45 \times 10^{4}\right), 359\left(2.01 \times 10^{4}\right) \mathrm{nm} .{ }^{1} \mathrm{H}$ NMR $\left[400 \mathrm{MHz},\left(\mathrm{CD}_{3}\right)_{2} \mathrm{SO}, 25^{\circ} \mathrm{C}\right]: \delta=9.74(\mathrm{~s}, 1 \mathrm{H},-\mathrm{NH}), 9.64(\mathrm{~d}, J=$ $2.65 \mathrm{~Hz}, 1 \mathrm{H},-\mathrm{NH}), 8.42-8.41$ (d, $J=3.24 \mathrm{~Hz}, 1 \mathrm{H}, \mathrm{Ar}-\mathrm{H}), 8.34$ $8.33(\mathrm{~d}, J=3.22 \mathrm{~Hz}, 1 \mathrm{H}, \mathrm{Ar}-\mathrm{H}), 8.27$ (s, $1 \mathrm{H}, \mathrm{Ar}-\mathrm{H}), 8.13-8.11$ (t, $J=3.97 \mathrm{~Hz}, 1 \mathrm{H}, \mathrm{Ar}-\mathrm{H}), 7.89-7.86$ (m, $1 \mathrm{H}, \mathrm{Ar}-\mathrm{H}), 7.72-7.69$ (m, $1 \mathrm{H}, \mathrm{Ar}-\mathrm{H}), 7.61$ (s, $1 \mathrm{H}, \mathrm{Ar}-\mathrm{H}), 6.95-6.91(\mathrm{~m}, 1 \mathrm{H}, \mathrm{Ar}-\mathrm{H}), 6.77$ (s, $1 \mathrm{H}, \mathrm{Ar}-\mathrm{H}$ ), 2.29 (s, $3 \mathrm{H},-\mathrm{CH}_{3}$ ) ppm. $\mathrm{C}_{15} \mathrm{H}_{14} \mathrm{~N}_{6}$ (278.32): calcd. C 64.73, H 5.07, N 30.20; found C 64.64, H 5.19, N 30.14 .

$N^{2}$-(4-Methylpyridin-2-yl)- $N^{6}$-(pyrazin-2-yl)pyrazine-2,6-diamine (mpzpzda) (3): The preparation process for $\mathbf{3}$ was similar to that of 1 except that $N$-(6-chloropyrazin-2-yl)pyrazin-2-amine $(4.15 \mathrm{~g}$, $0.02 \mathrm{~mol}$ ) was used instead of $N$-(6-bromopyridin-2-yl)pyrazin-2amine, the reaction time was $72 \mathrm{~h}$, and dichloromethane/acetone (1:1) was used as eluent for column chromatography. Yield: $3.46 \mathrm{~g}$, $62 \%$; m.p. $235^{\circ} \mathrm{C}$. IR (KBr): $\tilde{v}=3270(\mathrm{~m}), 3152(\mathrm{~m}), 3056(\mathrm{~m})$, 3004 (m), 1619 (m), 1603 (m), 1518 (m), 1492 (m), 1421 (s), 1328 (m), $1312(\mathrm{~m}), 1251$ (w), $1197(\mathrm{~m}), 1167$ (s), $1076(\mathrm{w}), 1010(\mathrm{~m})$, $996(\mathrm{~m}), 876(\mathrm{w}), 817(\mathrm{~m}), 470(\mathrm{w}), 420(\mathrm{w}) \mathrm{cm}^{-1}$. UV/Vis $\left(\mathrm{CH}_{3} \mathrm{OH}\right)$ : $\lambda\left(\varepsilon, \mathrm{dm}^{3} \mathrm{~mol}^{-1} \mathrm{~cm}^{-1}\right)=204\left(1.69 \times 10^{4}\right), 260\left(2.82 \times 10^{4}\right), 274$ $\left(2.77 \times 10^{4}\right), 366\left(2.46 \times 10^{4}\right) \mathrm{nm} .{ }^{1} \mathrm{H}$ NMR [400 MHz, $\left(\mathrm{CD}_{3}\right)_{2} \mathrm{SO}$, $\left.25^{\circ} \mathrm{C}\right]: \delta=10.08(\mathrm{~s}, 1 \mathrm{H},-\mathrm{NH}), 9.76(\mathrm{~s}, 1 \mathrm{H},-\mathrm{NH}), 9.29(\mathrm{~d}, J=$ $1.36 \mathrm{~Hz}, 1 \mathrm{H}, \mathrm{Ar}-\mathrm{H}), 8.56$ (s, $1 \mathrm{H}, \mathrm{Ar}-\mathrm{H}), 8.30-8.29$ (m, $1 \mathrm{H}, \mathrm{Ar}-$ $\mathrm{H}), 8.26(\mathrm{~s}, 1 \mathrm{H}, \mathrm{Ar}-\mathrm{H}), 8.17-8.16(\mathrm{~d}, J=2.59 \mathrm{~Hz}, 1 \mathrm{H}, \mathrm{Ar}-\mathrm{H})$, 8.14-8.12 (d, $J=5.10 \mathrm{~Hz}, 1 \mathrm{H}, \mathrm{Ar}-\mathrm{H}), 7.50$ (s, $1 \mathrm{H}, \mathrm{Ar}-\mathrm{H}), 6.79$ 
$6.77(\mathrm{~d}, J=5.06 \mathrm{~Hz}, 1 \mathrm{H}, \mathrm{Ar}-\mathrm{H}), 2.30\left(\mathrm{~s}, 3 \mathrm{H},-\mathrm{CH}_{3}\right) \mathrm{ppm}$. $\mathrm{C}_{14.5} \mathrm{H}_{15} \mathrm{~N}_{7} \mathrm{O}_{0.5}\left[3 \cdot 0.5 \mathrm{CH}_{3} \mathrm{OH}\right](295.33)$ : calcd. C 58.97, $\mathrm{H} 5.12, \mathrm{~N}$ 33.20; found C 59.26, H 4.85, N 33.60 .

$N^{2}$-(Pyrazin-2-yl)- $N^{6}$-(pyridin-2-yl)pyrazine-2,6-diamine (pzpzda) (4): The preparation process for $\mathbf{4}$ was similar to that of $\mathbf{1}$ except that $N$-(6-chloropyrazin-2-yl)pyrazin-2-amine (4.15 g, $0.02 \mathrm{~mol})$ and pyridine-2-amine (2.26 g, $0.024 \mathrm{~mol})$ were used as starting materials and dichloromethane/acetone (1:1) was used as eluent for column chromatography. Yield: 3.60 g, $68 \%$; m.p. $271{ }^{\circ} \mathrm{C}$. IR $(\mathrm{KBr}): \tilde{v}=3395(\mathrm{w}), 3248(\mathrm{~m}), 3100(\mathrm{~m}), 3055(\mathrm{~m}), 1610(\mathrm{~s}), 1586$ (m), $1530(\mathrm{~s}), 1069(\mathrm{~m}), 1482(\mathrm{~m}), 1428$ (s), $1346(\mathrm{~m}), 1307(\mathrm{~m})$, 1240 (m), 1189 (m), 1162 (m), 1144 (m), 1076 (w), 1058 (w), 1006 (w), 990 (m), 860 (w), $834(\mathrm{~m}), 764(\mathrm{~m}), 729(\mathrm{w}), 474(\mathrm{w}), 418(\mathrm{w})$ $\mathrm{cm}^{-1}$. UV/Vis $(\mathrm{DMF}): \lambda\left(\varepsilon, \mathrm{dm}^{3} \mathrm{~mol}^{-1} \mathrm{~cm}^{-1}\right)=204\left(6.70 \times 10^{3}\right), 262$ $\left(1.88 \times 10^{4}\right), 272\left(1.82 \times 10^{4}\right), 362\left(1.59 \times 10^{4}\right), 367\left(1.54 \times 10^{4}\right) \mathrm{nm}$. ${ }^{1} \mathrm{H}$ NMR [400 MHz, $\left.\left(\mathrm{CD}_{3}\right)_{2} \mathrm{SO}, 25^{\circ} \mathrm{C}\right]: \delta=10.08(\mathrm{~s}, 1 \mathrm{H},-\mathrm{NH})$, 9.85 (s, $1 \mathrm{H},-\mathrm{NH}), 9.21$ (d, $J=1.45 \mathrm{~Hz}, 1 \mathrm{H}, \mathrm{Ar}-\mathrm{H}), 8.62$ (s, $1 \mathrm{H}$, Ar-H), 8.40 (s, 1 H, Ar-H), 8.29-8.27 (m, 2 H, Ar-H), 8.15 (d, $J=$ $2.6 \mathrm{~Hz}, 1 \mathrm{H}, \mathrm{Ar}-\mathrm{H}), 7.70-7.69$ (m, $2 \mathrm{H}, \mathrm{Ar}-\mathrm{H}), 6.95-6.92$ (m, $1 \mathrm{H}$, Ar-H) ppm. $\mathrm{C}_{13} \mathrm{H}_{11} \mathrm{~N}_{7}$ (265.28): calcd. C 58.86, H 4.18, N 36.96; found C 58.49, H 4.25, N 36.88 .

Preparation of Complexes 5-8: The preparation processes for complexes 5-8 are very similar; hence, a general procedure is given for 5.

[Cu( $\mu$-mpypzda $\left.)\left(\mathrm{H}_{2} \mathrm{O}\right)\right]_{n}\left(\mathrm{ClO}_{4}\right)_{2 n}$ (5): A mixture of $\mathbf{1}(0.050 \mathrm{~g}$, $0.18 \mathrm{mmol})$ and $\mathrm{Cu}\left(\mathrm{ClO}_{4}\right)_{2} \cdot 6 \mathrm{H}_{2} \mathrm{O}(0.073 \mathrm{~g}, 0.20 \mathrm{mmol})$ in methanol $(30 \mathrm{~mL})$ was stirred overnight. Then the solution was filtered to remove insoluble impurities. Diffusing ether into the filtrate provided yellow-brown single crystals suitable for X-ray analysis. Yield: $0.083 \mathrm{~g}, 80 \%$. IR (KBr): $\tilde{v}=3498(\mathrm{~m}), 3320(\mathrm{~m}), 3262(\mathrm{~m})$, 3210 (m), 3099 (m), 1651 (m), 1592 (m), 1572 (m), 1548 (m), 1514 (m), 1487 (m), 1452 (s), 1409 (w), 1360 (w), $1283(\mathrm{w}), 1222$ (m), 1112 (s), 1089 (s), 1036 (m), 876 (w), 792 (m), 734 (w), 626 (m), 452 (w) $\mathrm{cm}^{-1}$. UV/Vis $\left(\mathrm{CH}_{3} \mathrm{OH}\right): \lambda\left(\varepsilon, \mathrm{dm}^{3} \mathrm{~mol}^{-1} \mathrm{~cm}^{-1}\right)=221$ $\left(1.78 \times 10^{4}\right), 241\left(1.75 \times 10^{4}\right), 259\left(1.63 \times 10^{4}\right), 304\left(1.47 \times 10^{4}\right), 322$ $\left(1.63 \times 10^{4}\right), \quad 351 \quad\left(1.07 \times 10^{4}\right), \quad 469 \quad(75.5), \quad 655 \quad(28.8) \quad \mathrm{nm}$. $\mathrm{C}_{15} \mathrm{H}_{18} \mathrm{Cl}_{2} \mathrm{CuN}_{6} \mathrm{O}_{10}$ [5· $\left.\mathrm{H}_{2} \mathrm{O}\right]$ (576.79): calcd. C 31.24, $\mathrm{H} 3.14, \mathrm{~N}$ 14.57; found C 31.31, H 3.18, N 14.85.
[Cu( $\mathbf{C}$-mpzpyda) $\left.\left(\mathrm{H}_{2} \mathbf{O}\right)_{2}\right]_{n}\left(\mathbf{C l O}_{4}\right)_{2 n}$ (6): Yield: $0.081 \mathrm{~g}, 76 \%$ on the basis of $0.050 \mathrm{~g}$ of ligand. IR $(\mathrm{KBr}): \tilde{\mathrm{v}}=3610(\mathrm{~m}), 3474(\mathrm{~m}), 3320$ (m), 3207 (m), 3095 (m), 1652 (m), 1634 (m), 1580 (m), 1549 (m), 1565 (m), 1515 (m), 1576 (s), 1432 (m), 1400 (w), 1371 (w), 1349 (w), $1297(\mathrm{w}), 1241(\mathrm{~m}), 1196(\mathrm{~m}), 1177$ (m), 1160 (m), $1094(\mathrm{~s})$, $1020(\mathrm{~m}), 956(\mathrm{w}), 739(\mathrm{~m}), 668(\mathrm{~m}), 626(\mathrm{~m}), 584(\mathrm{w}), 552(\mathrm{w}), 523$ (m), $477(\mathrm{~m}) \mathrm{cm}^{-1}$. UV/Vis $\left(\mathrm{CH}_{3} \mathrm{OH}\right): \lambda\left(\varepsilon, \mathrm{dm}^{3} \mathrm{~mol}^{-1} \mathrm{~cm}^{-1}\right)=209$ $\left(2.32 \times 10^{4}\right), 236\left(1.70 \times 10^{4}\right), 258\left(1.40 \times 10^{4}\right), 310\left(1.58 \times 10^{4}\right), 375$ $\left(1.29 \times 10^{4}\right), 658(47.0) \mathrm{nm} . \mathrm{C}_{15} \mathrm{H}_{20} \mathrm{Cl}_{2} \mathrm{CuN}_{6} \mathrm{O}_{11}\left[6 \cdot \mathrm{H}_{2} \mathrm{O}\right](594.81)$ : calcd. C 30.29, H 3.39, N 14.13; found C 29.98, H 2.99, N 13.65.

$\left[\mathbf{C u}(\mu \text {-mpzpzda })\left(\mathrm{H}_{2} \mathrm{O}\right)\left(\mathrm{CH}_{3} \mathbf{O H}\right)\right]_{n}\left(\mathrm{ClO}_{4}\right)_{2 n}$ (7): Yield: $0.074 \mathrm{~g}, 68 \%$ on the basis of $0.050 \mathrm{~g}$ of ligand. IR $(\mathrm{KBr}): \tilde{v}=3486(\mathrm{~m}), 3315$ (m), 3091 (m), 1651 (m), 1634 (m), 1547 (m), 1507 (m), 1483 (s), 1428 (m), 1404 (m), 1287 (w), 1241 (w), 1192 (m), 1146 (s), 1112 (s), $1086(\mathrm{~s}), 941(\mathrm{w}), 836(\mathrm{w}), 740(\mathrm{w}), 637(\mathrm{~m}), 626(\mathrm{~m}), 460(\mathrm{w})$, 424 (w) $\mathrm{cm}^{-1}$. UV/Vis $\left(\mathrm{CH}_{3} \mathrm{OH}\right): \lambda\left(\varepsilon, \mathrm{dm}^{3} \mathrm{~mol}^{-1} \mathrm{~cm}^{-1}\right)=216$ $\left(2.45 \times 10^{4}\right), 241\left(1.80 \times 10^{4}\right), 262\left(1.70 \times 10^{4}\right), 304\left(1.39 \times 10^{4}\right), 333$ $\left(1.39 \times 10^{4}\right), 380\left(1.45 \times 10^{4}\right), 632(50.6) \mathrm{nm} . \mathrm{C}_{15} \mathrm{H}_{21} \mathrm{Cl}_{2} \mathrm{CuN}_{7} \mathrm{O}_{11}$ [7· $\left.\mathrm{H}_{2} \mathrm{O}\right]$ : (609.82): calcd. C 29.54, H 3.47, N 16.08; found C 29.31, H 3.14, N 16.17 .

[Cu( $\mathbf{C}$-pzpzda) $\left.\left(\mathrm{H}_{\mathbf{2}} \mathbf{O}\right)_{2}\right]_{n}\left(\mathbf{C l O}_{4}\right)_{2 \boldsymbol{n}}$ (8): Yield: $0.088 \mathrm{~g}, 78 \%$ based on $0.050 \mathrm{~g}$ of ligand. IR $(\mathrm{KBr}): \tilde{v}=3592(\mathrm{~m}), 3474(\mathrm{~m}), 3324(\mathrm{~m})$, 3099 (m), 1648 (m), 1626 (m), 1592 (m), 1563 (m), 1549 (m), 1509 (m), 1471 (s), 1366 (w), 1344 (w), 1291 (w), 1242 (w), $1196(\mathrm{w})$, 1149 (w), 1100 (s), 930 (w), $883(\mathrm{w}), 849(\mathrm{~m}), 782(\mathrm{~m}), 623(\mathrm{~m}), 522$ (w), $448(\mathrm{w}) \mathrm{cm}^{-1}$. UV/Vis $\left(\mathrm{CH}_{3} \mathrm{OH}\right): \lambda\left(\varepsilon, \mathrm{dm}^{3} \mathrm{~mol}^{-1} \mathrm{~cm}^{-1}\right)=206$ $\left(1.80 \times 10^{4}\right), 241\left(1.55 \times 10^{4}\right), 262\left(1.47 \times 10^{4}\right), 309\left(1.21 \times 10^{4}\right), 333$ $\left(1.24 \times 10^{4}\right), 379\left(1.25 \times 10^{4}\right), 653(30.0) \mathrm{nm} . \mathrm{C}_{13} \mathrm{H}_{19} \mathrm{Cl}_{2} \mathrm{CuN}_{7} \mathrm{O}_{12}$ [8. $\mathrm{H}_{2} \mathrm{O}$ ] (599.78): calcd. C 26.03, H 3.19, N 16.35; found C 25.81, H 3.07, N 16.10.

$\left[\mathbf{C u}\left(\mu_{3}-\mathrm{H}_{2} \text { dpzpda)(NCS) }\right]_{n}\left(\mathbf{C l O}_{4}\right)_{n}\right.$ (9): A mixture of $\mathrm{H}_{2} \mathrm{dpzpda}$ $(0.050 \mathrm{~g}, 0.19 \mathrm{mmol})$ and $\mathrm{Cu}\left(\mathrm{ClO}_{4}\right)_{2} \cdot 6 \mathrm{H}_{2} \mathrm{O}(0.139 \mathrm{~g}, 0.38 \mathrm{mmol})$ in methanol $(25 \mathrm{~mL})$ was stirred for $1 \mathrm{~d}$. Then, NaNCS $(0.016 \mathrm{~g}$, $0.20 \mathrm{mmol})$ in methanol $(25 \mathrm{~mL})$ was added to the solution. After stirring for $1 \mathrm{~d}$, the solution was filtered to remove insoluble impurities. Slow evaporation of the filtrate gave green crystals suitable for X-ray diffraction. Yield: $0.11 \mathrm{~g}, 12 \%$ on the basis of $\mathrm{H}_{2}$ dpzpda. IR (KBr): $\tilde{v}=3307$ (w), 3242 (w), 3170 (w), 3107 (w), 2113 (s),

Table 5. Crystal data for compounds 5-9.

\begin{tabular}{|c|c|c|c|c|c|}
\hline Compound & $5 \cdot \mathrm{H}_{2} \mathrm{O} \cdot 0.5 \mathrm{C}_{2} \mathrm{H}_{5} \mathrm{OC}_{2} \mathrm{H}_{5}$ & 6 & 7 & 8 & 9 \\
\hline Formula & $\mathrm{C}_{17} \mathrm{H}_{23} \mathrm{Cl}_{2} \mathrm{CuN}_{6} \mathrm{O}_{10.5}$ & $\mathrm{C}_{15} \mathrm{H}_{18} \mathrm{Cl}_{2} \mathrm{CuN}_{6} \mathrm{O}_{10}$ & $\mathrm{C}_{15} \mathrm{H}_{15} \mathrm{Cl}_{2} \mathrm{CuN}_{7} \mathrm{O}_{10}$ & $\mathrm{C}_{13} \mathrm{H}_{15} \mathrm{Cl}_{2} \mathrm{CuN}_{7} \mathrm{O}_{10}$ & $\mathrm{C}_{28} \mathrm{H}_{22} \mathrm{Cl}_{2} \mathrm{Cu}_{2} \mathrm{~N}_{16} \mathrm{O}_{8} \mathrm{~S}_{2}$ \\
\hline Formula mass & 613.85 & 576.79 & 587.78 & 563.76 & 972.72 \\
\hline Crystal system & monoclinic & orthorhombic & orthorhombic & orthorhombic & triclinic \\
\hline Space group & $P 2_{1} / c$ & Pcca & Pcca & Pccn & $P \overline{1}$ \\
\hline$a[\AA]$ & $13.3794(9)$ & $20.0416(15)$ & $20.8397(14)$ & $19.9336(11)$ & $9.0106(5)$ \\
\hline$b[\AA]$ & $17.8630(11)$ & $8.0392(8)$ & $8.2339(5)$ & $8.2299(5)$ & $11.2560(7)$ \\
\hline$c[\AA]$ & $10.7329(7)$ & $13.6938(13)$ & $13.6452(9)$ & $13.6613(8)$ & $18.8139(11)$ \\
\hline$a\left[^{\circ}\right]$ & 90 & 90 & 90 & 90 & $98.540(1)$ \\
\hline$\beta\left[^{\circ}\right]$ & $95.444(2)$ & 90 & 90 & 90 & $96.243(1)$ \\
\hline$\gamma\left[^{\circ}\right]$ & 90 & 90 & 90 & 90 & $90.574(1)$ \\
\hline Volume $\left[\AA^{3}\right], Z$ & $2553.6(3), 4$ & $2203.4(3), 4$ & $2341.43(3), 4$ & $2241.2(2), 4$ & $1875.16(19), 2$ \\
\hline Absorption coefficient $\left[\mathrm{mm}^{-1}\right]$ & 1.129 & 1.300 & 1.227 & 1.277 & 1.460 \\
\hline Crystal size $[\mathrm{mm}]$ & $0.32 \times 0.26 \times 0.10$ & $0.25 \times 0.25 \times 0.08$ & $0.60 \times 0.25 \times 0.02$ & $0.25 \times 0.25 \times 0.10$ & $0.25 \times 0.20 \times 0.05$ \\
\hline$\theta$ range for data collection $\left[^{\circ}\right]$ & $1.53-27.50$ & $2.04-27.49$ & $1.95-25.00$ & $2.04-27.48$ & $1.10-27.50$ \\
\hline Reflections collected & 25143 & 12465 & 13304 & 16080 & 24822 \\
\hline Independent reflections & $5852\left(R_{\mathrm{int}}=0.0548\right)$ & $2532\left(R_{\mathrm{int}}=0.0870\right)$ & $2069\left(R_{\mathrm{int}}=0.1000\right)$ & $2571\left(R_{\mathrm{int}}=0.0858\right)$ & $8605\left(R_{\mathrm{int}}=0.0342\right)$ \\
\hline$R_{1}$ & 0.0904 & 0.0790 & 0.1050 & 0.0806 & 0.0658 \\
\hline$R w_{2}[I>2 \sigma(I)]$ & 0.2467 & 0.1804 & 0.2483 & 0.2124 & 0.1316 \\
\hline$R_{1}$ & 0.1141 & 0.1379 & 0.1306 & 0.0980 & 0.0764 \\
\hline$R w_{2}$ (all data) & 0.2684 & 0.2046 & 0.2638 & 0.2230 & 0.1381 \\
\hline Gof & 1.137 & 1.095 & 1.155 & 1.162 & 1.192 \\
\hline
\end{tabular}


$1649(\mathrm{~m}), 1624(\mathrm{w}), 1590(\mathrm{w}), 1556(\mathrm{~m}), 1501(\mathrm{~s}), 1472(\mathrm{~m}), 1451$ (s), $1401(\mathrm{w}), 1351(\mathrm{w}), 1298$ (w), $1223(\mathrm{~m}), 1194(\mathrm{w}), 1152$ (s), 1076 (s), $1034(\mathrm{~m}), 840(\mathrm{~m}), 796(\mathrm{~m}), 623(\mathrm{w}), 456(\mathrm{w}) \mathrm{cm}^{-1}$. UV/Vis $\left(\mathrm{CH}_{3} \mathrm{OH}\right): \lambda\left(\varepsilon, \mathrm{dm}^{3} \mathrm{~mol}^{-1} \mathrm{~cm}^{-1}\right)=206\left(2.79 \times 10^{4}\right), 244\left(1.76 \times 10^{4}\right)$, $263\left(1.85 \times 10^{4}\right), 316\left(1.76 \times 10^{4}\right), 336\left(1.75 \times 10^{4}\right), 653(99.4) \mathrm{nm}$. $\mathrm{C}_{14} \mathrm{H}_{13} \mathrm{ClCuN}_{8} \mathrm{O}_{5} \mathrm{~S}\left[9 \cdot \mathrm{H}_{2} \mathrm{O}\right]$ (504.37): calcd. C 33.34, $\mathrm{H} 2.60, \mathrm{~N}$ 22.22; found C 33.35, H 2.66, N 22.09.

Crystal Structure Determinations: The chosen crystals were mounted on a glass fiber. Data collection was carried out at $150(1) \mathrm{K}$ by using Mo- $K_{\alpha}$ radiation $(\lambda=0.71073 \AA)$ and a liquid nitrogen low-temperature controller on a BRUKER SMART ApexCCD diffractometer. Data reduction was performed with the Bruker SAINT. Semiempirical absorption corrections were applied. All the structures were solved by using the SHELXL-97 and refined with SHELXL-97 by full-matrix least-squares on $F^{2}$ values. The detailed crystal data are listed in Table 5.

CCDC-647770, -647771, -647772, -647773, and -647774 contain the supplementary crystallographic data for compounds 5-9 for this paper. These data can be obtained free of charge from The Cambridge Crystallographic Data Centre via www.ccdc.cam.ac.uk/ data_request/cif.

Supporting Information (see also the footnote on the first page of this article): Syntheses of starting materials $N$-(6-bromopyridin-2yl)pyrazin-2-amine (1S), 6-chloro- $N$-(pyridin-2-yl)pyrazin-2-amine (2S), and $N$-(6-chloropyrazin-2-yl)pyrazin-2-amine (3S); ORTEP drawing of the structure of 7; temperature dependence of the magnetic moment; and the molar susceptibility for $\mathbf{6}$ and $\mathbf{8}$.

\section{Acknowledgments}

The authors thank the National Science Council of the Republic of China for financial support and Mr. Bor-Wen Shih for his help with magnetic measurement.
[1] a) J. Carranza, J. Sletten, C. Brennan, F. Lloret, J. Cano, M. Julve, Dalton Trans. 2004, 3997-4005; b) M. Inoue, M. Kubo, Coord. Chem. Rev. 1976, 21, 1; c) H. W. Richardson, W. E. Hatfield, J. Am. Chem. Soc. 1976, 98, 835-839.

[2] a) J. F. Berry, F. A. Cotton, T. Lu, C. A. Murillo, B. K. Roberts, X. Wang, J. Am. Chem. Soc. 2004, 126, 7082-7096; b) C.-Y. Yeh, C.-C. Wang, Y.-H. Chen, S.-M. Peng in Redox Systems Under Nano-Space Control (Ed.: T. Hirao), Springer, Germany, 2006, ch. 5.

[3] a) R. H. Ismayilov, W.-Z. Wang, R.-R. Wang, C.-Y. Yeh, G.H. Lee, S.-M. Peng, Chem. Commun. 2007, 1121-1123; b) W.Z. Wang, R. H. Ismayilov, G.-H. Lee, I. P.-C. Liu, C.-Y. Yeh, S.-M. Peng, Dalton Trans. 2007, 830-839.

[4] a) R. H. Ismayilov, W.-Z. Wang, G.-H. Lee, S.-M. Peng, Dalton Trans. 2006, 478-491; b) R. H. Ismayilov, W.-Z. Wang, G.-H. Lee, R.-R. Wang, I. P.-H. Liu, C.-Y. Yeh, S.-M. Peng, Dalton Trans. 2007, 2898-2907.

[5] W. Hiller, J. Strähle, A. Datz, M. Hanack, W. E. Hartfield, L. W. T. Haar, P. Gütlich, J. Am. Chem. Soc. 1984, 106, 329335.

[6] a) J. Darriet, M. S. Haddad, E. N. Duesler, D. N. Hendrickson, Inorg. Chem. 1979, 18, 2679-2682; b) H. W. Richardson, J. R. Wasson, W. E. Hatfield, Inorg. Chem. 1977, 16, 484486.

[7] M. J. Sanchis, P. Gómez-Romero, J. V. Folgado, F. Sapiña, R. Ibáñez, A. Beltrán, J. García, D. Beltrán, Inorg. Chem. 1992, 31, 2915-2919.

[8] J. L. Manson, J. G. Lecher, J. Gu, U. Geiser, J. A. Schlueter, R. Henning, X. Wang, A. J. Schultz, H.-J. Koo, M.-H. Whangbo, Dalton Trans. 2003, 2905-2911.

[9] a) H. Yahiro, K. Kimoto, H. Yamaura, K. Komaguchi, A. Lund, Chem. Phys. Lett. 2005, 415, 126-130; b) B. Figgis, M. Hitchman, Ligand Field Theory and Its Applications, WileyVCH, America, 2000, ch. 10; c) D. Ghosh, N. Kundu, G. Maity, K.-Y. Choi, A. Caneschi, A. Endo, M. Chaudhury, Inorg. Chem. 2004, 43, 6015-6023; d) P. Cheng, L.-G. Bai, D.-Z. Liao, S.-P. Yan, Z.-H. Jiang, G.-L. Wang, Polyhedron 1995, 14, 25192521.

Received: August 25, 2007 Published Online: November 12, 2007 